\title{
SİCILLER IŞIĞINDA MEŞAKKATLİ BİR İBADET OLAN HAC VE OSMANLI HACILARI
}

\section{Nevzat ERKAN ${ }^{1}$}

\begin{abstract}
Öz
Hac ibadeti, tabiatı gereği pek çok zorluğu beraberinde getirdiği için tarih boyunca Müslüman toplumlarda en fazla dikkat çeken mevzular arasında yer almıştır. Osmanlıda haciların toplumsal statüleri, hac için yapılan hazırlıklar, gidiş-dönüş yolunda vuku bulan vefatlar ve bu çerçevede yapılan uygulamalar üzerinde duracağımız konulardandır. Bunların yanı sira hac yolunda vefat eden kișilerin miras hukukuna ilişkin olarak borç-alacak davaları, sahip oldukları kölelerin durumları gibi çeșitli meselelere de yer verilecektir. Hac yolculuğu sonrası hacıların karşılaştıkları zorluklar, farklı sebeplerden dolayı hacca gidemeyen insanların hac vasiyetleri de bu çalışmanın kapsaminda yer almaktadır.

Bu makalede Osmanl Devleti tarafindan yapilan hac organizasyonundan ziyade hac yolculuğuna çıkmış insanların tecrübeleri mahkeme kayıtlarından hareketle ele alınacaktır. Konuyla ilgili bazı çalışmalar yapılmış olsa da daha geniş kapsamlı çalıșmalara ihtiyaç vardır. Dönem olarak 16. ve 18. Asır mahkeme kayıtları esas alınmakla birlikte daha eski tarihlere ait kayitlar da değerlendirilecektir. Diğer Osmanlı șehirlerinde yaşayanlara kısmen değinilecek ancak makalenin odak noktasında İstanbul, Rumeli șehirleri ve Kıbrıs'ta yaşayan Müslümanların gerçekleștirdikleri hac yolculukları yer alacaktır. Vasiyyetleri

Anahtar Kelimeler: Osmanlı Hacıları, Hac Yolunda Vefat, Hac
\end{abstract}

\section{IN THE LIGHT OF KADI'S REGISTRIES A COMFORTABLE WORSHIP HAJI AND OTTOMAN'S PILGRIMS}

\begin{abstract}
Hajj worship has been one of the most prominent issues in Muslim societies throughout history as it brings many difficulties due to its nature. The social status of pilgrims in the Ottoman Empire, the preparations for the pilgrimage, the deaths on the way to and from the round trip, and the practices in this context are among the topics we will focus on. In addition to this, various issues such as debt-credit lawsuits, the status of slaves they possess will be included in relation to
\end{abstract}


the inheritance law of the persons who have died on the way of pilgrimage. The difficulties faced by the pilgrims after the pilgrimage journey, and the pilgrimage will of the people who cannot go to pilgrimage due to different reasons are also within the scope of this work.

In this article, the experiences of the people who went on a pilgrimage journey rather than the organization of pilgrimage made by the Ottoman State will be discussed from the court records. Although some studies have been conducted on the subject, more comprehensive studies are needed. The 16th and 18th century court records will be taken into consideration as well as the records of older dates. The inhabitants of other Ottoman cities will be mentioned in part, but the focus will be on the pilgrimage journeys of Muslims living in Istanbul, Rumelia and Cyprus.

Keywords: Ottoman Pilgrims, Death on the Way of Hajj, Hajj Testaments

\section{Giriş}

İslam'ın beş esasından biri olup gücü yeten Müslümanların ömründe bir defa yapması gereken ve her yll gerçekleşen hac ibadeti, farz kılındığı tarihten itibaren Müslümanlar açısından bir buluşma ve uğruna zahmet çekilen bir ibadet olmuştur.

Hz. Peygamber'in diğer ibadetlerden farklılığını ortaya koyan, hac ibadetinin meşakkatli yönüne dikkat çeken "Hacı, saçı dağınık, üstü-başı tozlu kimsedir" ${ }^{1}$ hadisinin de işaret ettiği üzere, hac ibadeti her dönemde, özellikle modern zamanlar öncesi şartları gereği zor ve meşakkatli bir ibadet olmuştur. Hulefâ-yı Râşidîn dönemi sonrası İslam coğrafyasının sınırlarının genişlemesiyle birlikte Müslüman devletlerin idarecileri hac yolunun emniyetini sağlamak ve hacıların ihtiyaçlarını gidermek için gayret sarf etmişlerdir. $\mathrm{Bu}$ meyanda

\footnotetext{
1 Yaygın kanaat "Hac meșakkattir." șeklinde bir hadisin olduğu yönündedir. Bunun bir darbımesel olduğu hadis kaynaklarında Hz. Peygamber (SAV)'in haccl kolaylaștırılması yönünde duasının bulunduğu ve hacıyı tarifinde metinde Türkçesi

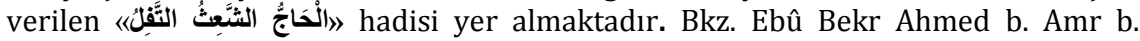
Abdilhâlik el-Bezzâr el-Basrî (ö. 292/905), el-Bahrü'z-Zehhâr (el-Müsned) (nşr. Mahfûzu'r-Rahmân Zeynullâh), Müessesetü 'Ulûmü'l-Kur'ân - Mektebetü'l-'Ulûm ve'l-Hikem, Beyrut-Medine: 1988, I, 285-286 (no: 182). (Hadisin tahrici için yardımcı olan Araş. Gör. Ali Yücel'e teșekkür ederim.)
} 
Emeviler döneminde Velid b. Abdülmelik ${ }^{2}$ ve Abbasiler döneminde Mehdi zamanında hacılar için pek çok su kuyuları açılmıș, hac yolları tamir edilmiştir. ${ }^{3}$ İsmi en çok hacceden halifeler arasında zikredilen Hârûnürreşîd'in hanımı Zübeyde Bağdat-Mekke yolunu tamir ettirmiştir. ${ }^{4} \mathrm{Bu}$ tür faaliyetler yöneticiler açısından prestij anlamına da gelmekle birlikte yapılan hizmetler bu zorlu ibadetin Müslümanlarca daha güvenli ve az zahmetli yapılmasını mümkün klliyordu.

Arap yarımadasındaki bedevi kabilelerin hac kervanlarına baskın ve yağma yapması tarih boyunca yöneticileri her daim tedbir almaya sevk etmiştir. ${ }^{5}$ Bunun için Hz. Peygamber zamanından itibaren süregelen emirü'l-hac uygulaması, hac ibadetinin devlet tarafından kurumsal olarak organize edilmesini sağlamıştır. Halifeler bu görevi ya kendileri bizzat üstlenmişler ya da tayin ettikleri hac emîrine havale etmişlerdir. ${ }^{6}$

Bedevi kabilelerinin hac kervanlarına saldırmalarının yanı sıra Karmati isyanları gibi iç meseleler Abbasiler döneminde hem haccın yapılmasını hem de hacıların yol güvenliğini tehlikeye düşürmekteydi. Zaman zaman Haremeyn toprakları dışındaki Müslüman toplumların kendi aralarındaki yoğun mücadeleler de hacıların Hicaz'a ulaşmasını engelleyebiliyordu.7 H.632/M.1235'de Eyyubiler ile Anadolu Selçukluları arasındaki mücadeleden dolayı Yemen ve Mısır tarafından deniz yoluyla haccedenler hariç Müslümanlar o yıl Haremeyn'e ulaşamamıștı. ${ }^{8}$ Endülüs bölgesindeki

\footnotetext{
2 Ebû Cafer İbn Cerir Muhammed b. Cerir b. Yezid Taberi (v. 310/92), Târihü'tTaberi: Târihü'l-Ümem ve'l-Mülûk thk. Muhammed Ebü'l-Fazl İbrâhim. Beyrut, 1967. Vl, 435-436; Mevlüt Koyuncu, "Velîd I" DİA, İstanbul 2013, XLIII, 31.

3 Taberi, a.g.e. VIII, 172-186; Mustafa S. Küçükaşçı, "Hicaz" DİA; İstanbul 1998, XVII,434; Nahide Bozkurt "Mehdî-bilâh" DİA İstanbul 2003, XXVIII,379.

${ }^{4}$ Abdülkerim Özaydın, "Hac: Tarihçe" DIA, İstanbul 1996, XIV, 399.

5 Küçükaşcl, Abbasiler'den Osmanlılar'a Mekke-Medine Tarihi, Yeditepe Yayınevi İstanbul 2007, s.224-228.

6 Münir Atalar "Emîr-i Hac" DİA, İstanbul 1995, XI, 131-132; Küçükaşçı, MekkeMedine Tarihi, s. 228-229.

7 Özaydın, a.g.m., s.399; Endülüs hacılarıyla beraber H.578/M.1183 yılında deniz yoluyla hacca giden İbn Cübeyr, yol boyunca çekilen sıkıntıları dile getirmiștir. Özellikle İskenderiye limanında yaşanan zorluklar Kızıldeniz'de hacıların boğulmaları ve Cidde'de bedevi kabilelerin soygunlarının hacıları zor durumda bıraktığından şikâyet etmektedir. Bkz. Ebü'l-Hüseyin Muhammed b. Ahmed İbn Cübeyr, (v.614/1217), Rihletu İbn Cübeyr, Dâru's-Sadr, Beyrut 1980, s. 13-14, 4655.

8 Ebü'l-Kâsım Şehabeddin Abdurrahman Ebû Şame el-Makdisi, (v.665/1268), elMüzeyyel ale'r-Ravzateyn : (tarihü'd-devleti'l-Eyyubiyye ma ba'de Salahiddin)
} 
Müslüman hükümdarlar Hıristiyanlar ile sürekli savaş hâlinde oldukları için kendileri haccedemedikleri gibi halklarına da hac izni vermemişler, bu sebeple çok az sayıda Endülüslü Müslüman haccetme imkânını elde edebilmiştir. ${ }^{9}$ Görüldügü üzere gerek Müslüman toplumların yaşadıkları bölgelerin siyasî şartları gerekse hac yollarının durumu hac yolculuğunu doğrudan etkilemekteydi.

Zaman içerisinde devlet gücünün yetmediği ve ulaşımın zor olduğu coğrafyalarda bazı tasavvuf ekollerinin hacıların yolculuğunu kolaylaştırmada etkin rol aldıkları görülmektedir. Buna en güzel örnek XIII. asırda Kuzey Afrika'da bedevi kabilelerinin saldırısına uğrayan hac kafilelerini sağ salim kutsal beldelere ulaştırmak için ortaya çıkmış, kurucusu Ebu Muhammed Salih adında bir şeyh olan Salihiye tarikatıdır. Bu tasavvufî grup, Mağrib'den Hicaz'a kadarki yol güzergâhında hacı adayları için sayıları kırk altıyı bulan özel zaviyeler ve konaklama merkezleri inşa ettirmiştir. İlave olarak hacıların bütün ihtiyaçlarını karşılayacak bir sosyal yapıyı oluşturmuş ve etrafındaki saliklerine de hem hac ibadetini ifa etmelerini hem de bu faaliyeti sürdürmelerini telkin etmiştir. ${ }^{10}$

Memlüklere son verip Mısır, Doğu Akdeniz ve Haremeyn topraklarını da içeren geniş coğrafyaya egemen olan Osmanlı Devleti yıkılışına kadar yaklaşık dört asır boyunca hac organizasyonunu uhdesine almıştır. Osmanlı Devleti, Memlüklerin yaptığı hac ile ilgili uygulamaları örnek aldığı gibi daha da geliştirmiştir. Hilafetin Bağdat'tan Kahire'ye intikaliyle hac emirleri Memlükler döneminde Kahire'den hareket ederken Osmanlılar Hac Emiri sayısını biri Şam ve diğeri Kahire olmak üzere ikiye çıkarmıştır.11 Abbasiler döneminde başlayan Mekke ve Medine'ye surre gönderme geleneği Osmanlılarda iyice tekâmül etmiştir. İstanbul'dan yola çıkan surre alayları belli merasim ve teşrifat kaideleri çerçevesinde bazı sıkıntılı yıllar hariç 1915 yılına kadar gönderilmeye devam etmiștir. ${ }^{12}$ Hicaz

Dımaşk: Darü'r-Risaleti'l-Alemiyye; Beyrut: Darü'l-Beşairi'l-İslamiyye, 2010/1431 ll, 31; Küçükaşçı, Mekke-Medine Tarihi, s 225.

9 Özaydın, a.g.m., s.400.

10 Geniş açıklamalar için bkz. Kadir Özköse, "Mağrib Müslümanlarının Hac Organizatörlüğünü Yapan Tarikat: Salihiyye Tarikatı ve Asafi Ribatı" Cumhuriyet Üniversitesi Illahiyat Fakültesi Dergisi, XI/1 Sivas 2007, 29-49.

11 Şam ve Mısır'a emîrül-hac tayin örnekleri için bkz. BOA, A.DVNSMHM.d 39/354 (25 Z 987/13 Ocak 1580), A.DVNSMHM.d 116/533 (20 Ra 1121/ 4 Haziran 1709); Atalar, a.g.m. s.132.

12 Osmanlı Devleti'inde hac ibadetinin merkezi olarak Hicaz, Sürre-i Hümayun adı altında resmi bir organizasyonları Gerek haccın siyasi boyutu gerekse hac kervanlarının sağlıklı bir şekilde gidip gelmesi, hacıların konakladıkları yer ile ilgili 
bölgesini sulhen kendi topraklarına dâhil eden Osmanlılar için hac ibadeti ve organizasyonu, İslâm dünyasının en güçlü devleti olmaları hasebiyle siyasî olduğu kadar dinî ve kültürel bir mesuliyet, aynı zamanda manevî bir meşruiyet kaynağı olarak telakki ediliyordu..$^{13}$ Yapılan araştırmalarda hac yollarının güvenliği ve yolların açık tutulması için, diğer katkılar hariç, merkezi bütçenin yaklaşık \%2'sine tekabül eden mühim miktarda parayı Osmanlıların bu iş için kullandıkları belirtilmektedir. ${ }^{14}$ Haremeyn'e hizmet etme saikiyle pek çok vakıf kurulmuş ve gelirleri bu yolda harcanmıștır. ${ }^{15}$

Osmanlılar döneminde Evliya Çelebi'nin Seyahatnamesi başta olmak üzere çeşitli seyahatname veya hac rehberi tarzında manzum ve mensur eserler kaleme alınmıștır.16 Söz konusu eserlere ek olarak

pek çok çalışma yapılmıştır. Tafsilatlı bilgiler için bkz. İsmail, Hakkı Uzunçarşıll, Mekke-i Mükerreme Emirleri, TTK, Ankara 1984, Münir Atalar, Osmanlı Devleti'nde Surre-i Hümayun ve Surre Alayları, Diyanet İșleri Bașkanlı̆̆ı, Ankara 1991, Me'mun Abdullah Aslan Beni Yunus, Kafiletü'l-haci'ş-Șami fi șarkıyyi'l-Ürdün fíl-ahdi'l-Osmani : 1516-1918,: Vizaretü's-Sekâfe, Amman 1997.

13Zekeriya Kurşun, “Hac ve İktidar:Haremeyn'de Erken Dönem Osmanlı İmar Faaliyetleri" FSM İlmî Araștırmalar İnsan ve Toplum Bilimleri Dergisi İstanbul 2017, IX,284.

14 Faroqhi, Haclar ve Sultanlar s.86-89; Karl K. Barbir, Ottoman Rule in Damascus : 1708-1758. : Princeton University, Princeton 1980, s.110-132.

15 Osmanlı öncesi Memlüklüler döneminde Haremeyn için vakıflar kurulmuştur. bkz. Fatih Yahya Ayaz, Bahri Memlukler Döneminde Hararmeyn Hizmetleri, Marmara Üniversitesi SBE (Basılmamış Y. Lisans Tezi) İstanbul 1998, s. 47-50. Osmanlı'da ise daha Hicaz bölgesini alınmadan önce Haremeyn'e yönelik vakıflar tesis edilmiștir. Bkz. İsmail Hakkı Uzunçarşıll, "Sultan İkinci Murad'ın Vasiyetnâmesi" Vakıflar Dergisi, Ankara 1958 s VI, 4; Yavuz Sultan Selim döneminden itibaren bașta padişahlar ve saray halkı olmak üzere Haremeyne yönelik pek çok vakıf kurulmuştur. Bkz. Mustafa Güler, Osmanlı Devletinde Haremeyn Vakıfları (16. Ve 17. Yüzyıllar) İstanbul 2002; Macide Mahluf, Evkafu Nisai's-Selâtine'l- Osmaniyyîn: Vakfiyetü Zevceti's-Sultan Süleyman Kanuni ale'l-Haremeyni'ş-Şerifeyn. Darü'l-Afaki'lArabiyye, Kahire 2006.

16 Osmanlı kroniklerinin yanı sıra hac için en önemli eserlerden biri seyahatnamedir. 1671 yllında kendisinin de hac ibadetini yerine getirdiği Evliya Çelebi, seyahatnamesinin dokuzuncu. cildinde etraflıca haccı anlatmıștır. Bkz. Evliya Çelebi, (v.1095/1684) , Evliya Çelebi Seyahatnamesi:, haz. Yücel Dağlı, Seyit Ali Kahraman, Robert Dankoff, Yapı Kredi Yayınları, İstanbul 2005, IX, 286-430, Eserin değerlendirmesi için bkz. Nurettin Gemici, "Evliya Çelebi'nin Hac Ziyareti ve Seyahatname'nin Hac Bölümünün Kaynakları", Diyanet İlmi Dergi, 2009, C: XLV, say.: 3, s. 77-102; Hac rehberi tarzında başta Hibrî olmak üzere pek çok müellifin kaleme aldığı eser bulunmaktadır. Örnek çalışmalar için bkz. Sevim İlgürel, "Abdurrahman Hibri'nin Menasik-i Mesalik'i", İstanbul Üniversitesi Edebiyat Fakültesi Tarih Enstitüsü Dergisi, İstanbul 1975, Say.6 , s.111-128; A. Latif Armağan, "XVIII. Yüzyılda Hac Yolu Güzergâhı ve Menziller (=Menâzilü'l-Hacc)",Osmanlı Araştırmaları, İstanbul, 2000, Sayı: XX s. 73- 118; İzzet Sak, Cemal Çetin, "XVII. ve XVIII. Yüzyıllarda 
çeşitli arşiv ve kadı sicili kayıtları da Osmanlı dönemi hacıları ve hac yolculuğu üzerine yapılacak çalışmalarda mühim bir kaynak grubunu oluşturmaktadır. ${ }^{17}$ Bu çalışma da özellikle kadı sicillerini kullanarak Osmanlı toplumunda sıradan insanların hac için yaptığı hazırlıkları, hac yolunda çekilen meşakkatleri, hac yolculuğunda vefat gibi konuları ele alarak konuyla ilgili literatüre katkı sunmayı amaçlamaktadır.

\section{Mahkeme Kayıtlarında Hacılar}

Şer'iyye sicil kayıtlarında kişileri tanımlarken kullanılan, standartlaşmış belli tabirler (yazım usulleri) söz konusudur. Şahısların adları (baba adlarıyla birlikte), adresleri, meslekleri gibi onları tanımlayan bilgilerin yanı sıra toplumsal statüleri ve unvanları da kayıtlarda genellikle belirtilirdi. Bu çerçevede şer'iyye sicillerinde hatırı sayılır sayıda el-Hâc ünvanlı kişilere rastlanılmaktadır; ancak Osmanlı dönemi kayıtlarında yılda kaç kişinin hacca gittiğine dair bir bilgi bulunmadığından kesin sayı vermek mümkün gözükmemektedir. ${ }^{18}$ Tereke kayıtları bu açıdan başvurulabilecek kaynakların başında gelmektedir. Tereke çalışmalarının öncüsü kabul edilen Barkan'ın Edirne askerî kassâmlığı kayıtları üzerine yaptığı kapsamlı incelemesinde 74 tane sadece el-hâc ve 11 hâce ünvanlı tereke sahibi yer almaktadır. Barkan, bunların genellikle ticaret erbabı olduğunu tahmin etmektedir. Bu sayı Barkan'ın incelemesinde yer alan toplam 3128 tereke kaydının \% 2,7'sini

\footnotetext{
Osmanlı Hac Menzilleri” Selçuk Üniversitesi İlahiyat Fakültesi Dergisi, Konya 2005, say.19s. 199-260.

17 SuraiyaFaroqhi'nin Hacılar ve Sultanlar : Osmanlı Döneminde Hac : 1517-1638 adlı eseri ile Münir Atalar'ın Osmanlı Devleti'nde Surre-i Hümâyûn ve Surre Alayları başlıklı incelemesi Osmanlı dönemi hac konusunu ele alan çalışmaların başında gelmektedir. trc. Gül Çağalı Güven. Tarih Vakfı Yurt Yayınları İstanbul, 1995 adlı eserinin ilgili bölümleri ve Serdar genç tarafından sunulmuş " Hac Yolunda Ölüm: XVIII. Yüzyılda Balıkesirli Hacılar” Balıkesir Sempozyumu: Tebliğler Kitabı, 17-20 Kasım Balıkesir 2005, s.312-317 adlı tebliğini zikredebiliriz.

18 Hacı sayıları konusunda Osmanlı döneminde hacca giden Müslümanların sayım dökümü yapılmadığından seyyahların verdiği bilgilerden hareketle değișik rakamlar verilmektedir. Bkz. Faroqhi, Hacılar ve Sultanlar s.45; Abdülkadri Özcan, " Hac: Osmanlı Dönemi” DİA, İstanbul 1996, XIV, 402; 1880 yllında Cidde'de bulunan İngiliz WifredS. Blunt (1922) hangi bölgeden ne kadar hacının geldiğini belirttiği çalışmasında rakamları detaylı olarak vermiş, 1880 yılında kutsal beldelere toplam 93.000 hacının geldiğini bunun 61750sinin deniz yoluyla 31750'nin karayoluyla geldiğini, söylemektedir. Bkz. Blunt, İslamın Geleceği, trc. M. Fatih Karakaya, Ayrıntı Yayınları, İstanbul 2011, s. 17.
} 
oluşturmaktadır.19 Said Öztürk, İstanbul tereke defterlerine dayalı yaptığı çalışmasında bu kişilerin hac farizasını yerine getirmiş kimseler olmakla beraber farklı kullanımları olabileceğine dikkat çekmiştir. ${ }^{20}$ Hülya Canbakal ise, el-hâc tabirinin unvan olarak çok kullanılmasından ötürü bu kişilerin gerçekten hacı olup olmadığı konusunda kuşkusunu dile getirmiștir. ${ }^{21}$ Hacılar üzerine çalışmaları bulunan Suraiya Faroqhi, hacca gitmek için yeterli mal varlığına sahip olunması gerektiğinden hareketle mahkeme kayıtlarında yer alan el-hâc unvanlı kișileri hac görevini yerine getirmiș Müslümanlar olarak kabul etmiştir.22 Siciller üzerine yaptığımız çeşitli incelemelerden hareketle bizim de kanaatimiz el-hâc unvanı taşıyan kişilerin gerçekten hac ibadetini yapmış Müslümanlar olduğu yönündedir. ${ }^{23}$ Toplumsal muarefenin olduğu bu devirlerde, Hac ibadetinin maddî-manevî çeşitli zorluklarından ötürü bu unvanı hak edenlerin diğerlerinden ayırt edilmiş olduğunu düşünmekteyiz.

Maddî gereksinimlerin yanında hac yolculuğunun zorlu şartlarından dolayı el-hâc sıfatını taşıyan Müslümanların ekseriyetinin erkekler olması şaşırtıcı bir durum değildir. Tereke kayıtlarına dayalı olarak 17. asır İstanbul merkezli yapılan bir araştırmada tereke sahiplerinin ölümleri üzerinde de durulmuştur. Büyük çoğunluğu olağan vefatlardan oluşmakla birlikte bunların dışında ölümler de kayıtlarda yer almaktadır. Olağan dışı kabul edilen 226 vakıada tereke sahiplerinin ölüm sebepleri ve yerleri ile ilgili ayrıntılı bilgiler verilmiștir. Bu 226 tereke sahibi içinde 17'sinin ortak özelliği hac yolunda vefat etmiş olmalarıdır. İkisi kadın olan 17 kişilik grup bu araştırmada olağan dışı vefat edenlerin $\% 7,5^{\prime}$ ini teşkil etmektedir. ${ }^{24}$

\section{Hac Vasiyetleri}

Şer'iyye sicillerinde hacla ilgili olarak iki türlü vasiyetle karşılaşılmaktadır. Birincisi hacca gidecek insanların yaptığı vasiyet

\footnotetext{
19 Ömer Lütfi Barkan, "Edirne Askeri Kassamı'na Ait Tereke Defterleri (1545-1659)” Belgeler (Türk Tarih Belgeleri Dergisi), Ankara 1966, C. III, say. 5-6. sayı, s. 16.

${ }^{20}$ Said Öztürk, İstanbul Tereke Defterleri: Sosyo-Ekonomik Tahlil: Askeri Kassama Ait: Onyedinci Asır, Osmanlı Araştırmaları Vakfı İstanbul 1995, s. 123.

21 Hülya Canbakal, 17. Yüzyllda Ayntab: Osmanl Kentinde Toplum ve Siyaset, trc. Zeynep Yelçe, İletişim Yayınları, İstanbul 2009, s. 168.

22 Faroqhi, Orta Halli Osmanlılar:17.Yüzyılda Ankara ve Kayseri'de Ev Sahipleri ve Evler, trc. Hamit Çalışkan, Türkiye İş Bankası Kültür Yayınları, İstanbul 2009, s. 2223.

${ }^{23}$ Nevzat Erkan, Osmanlı Üsküdar'ında Toplumsal Hayat (18. Asır Üsküdar'da MüslimGayrimüslim İlişkileri), Üsküdar Belediyesi, İstanbul 2015, s. 133.

24 Said Öztürk, a.g.e., s. 137.
} 
ikincisi ise hacca gitmek nasip olmamış insanların hac vasiyetidir. Öncelikle kutsal yolculuğa karar vermiş ancak bu yolculuk esnasında vefat etme ihtimallerine karşıllk çeşitli içeriklere sahip vasiyetlerini kaleme aldırmış olan Müslümanlar söz konusudur. Herhangi bir vefat durumunda geride bıraktıkları mallarından (terekesinden) karşılanacak vasiyetlerin bedel olarak, ölüme bağlı diğer vasiyetlerde de olduğu üzere, toplam terekenin üçte birini geçmemesi gerekirdi. 25 Hacda ölüm ihtimaline binaen vasiyette bulunacak insanlar yaşadığ şehrin kadısına başvurarak bu arzularını gerçekleştirebilecekleri gibi, yol üzerindeki kadılıklarda kendi memleketlerinden hemșehrileri vasitasıyla vasiyetlerini kayda aldırabilmekteydiler.

Belgelerden anlaşıldığı kadarıyla vasiyette bulunan insanlar, kendilerine hizmeti geçmiş ancak hukuken terekesinden pay alamayacak (vâris statüsünde olmayan) kişiler lehine vasiyet hakkını kullanıyorlardı. El-Hâc Şaban b. Ali b. Abdullah'ın vasiyeti bu duruma güzel bir örnektir. Meşakkatli hac yolculuğuna çıkmadan, ölümü hâlinde terekesinin üçte birlik kısmıyla karşılanmak üzere vasiyette bulunan el-Hâc Şaban, kendisine mirasçı olamayacak iki kişiyi, müdebber kölesi Şahbat bt. Abdullah ile kayınvalidesi Hatice bt. Abdullah'ı vasiyetinden faydalanacak kişiler arasında zikretmekteydi. ${ }^{26}$ Diğer taraftan aslen Bosnalı olup İstanbul'da

\footnotetext{
25 Terekenin üçte birini aşan vasiyetlerin yerine getirilmesi ancak mirasçıların onayı ile mümkün olabilirdi. Vasiyyet ve ibadetlerdeki vasiyyetler için bkz. Ebu'l-Hasen Burhaneddin Ali b. Ebî Bekir Merginanî (v.593/1197) el- Hidaye Şerhu Bidâyeti'l Mübtedî Eda Neşriyat İstanbul 1991 ,I,136-137; Ömer Nasuhi Bilmen, Hukuk-ı İslâmiyye ve Istılahatı Flkhiyye Kamusu, İstanbul Üniversitesi Hukuk Fakültesi, İstanbul 1951, IV,„375-378.

26 Konuyla ilgili mahkeme kaydında: "Mahmiye-i İstanbul'da Hüsam Bey mahallesinde sâkin el-Hâc Şaban b. Ali b. Abdullah nâm kimesne meclis-i șer'-i şerîfde râfi'ü hâze'lkitâb el-Hâc Mehmed b. Mehmed nâm kimesne mahzarında ikrâr ve takrîr-i kelâm edip işbu sene-i mübârekede hacc-ı şerîfe azîmetim olmağın tarîk-i hacc-ı șerîfde bi emrillâhi te'âlâ fevt olduğumda cemî' malımdan mahrûse-i Galata'ya tâbi' kazâ-i Bandırma'da sâkin Abd[i] Bey nâm kimesne zimmetinde hakkım olan yüz elli esedî guruşum, merkūm Abdi Bey'den kabz olunup ve elli beș aded un çuvalım ve dört aded garar ve bir döşek ve bir yorgan ve bir kilim ve bir kürk ve bir kaftanım klymetleri ile âhara bey' ve semenleri meblağ-ı mezbûr yüz elli esedî guruşa zam olundukdan sonra meblağ-ı mezbûrun elli esedî guruşu müdebberem olan orta boylu, açık kaşlı siyah ala gözlü Gürciyye[tü]'l-asl Şahbaz bt. Abdullah'a verile ve bin akçesi dahi iskāt-ı salâtım için verile ve iki bin akçesi ile eyyâm-ı mu'tâdede tabh-ı ta'âm olunup fukarâya it'âm oluna. Bâkī her ne kalırsa kayınanam Hatice bt. Abdullah nâm hâtuna verile deyû vasiyyet ve tenfízine mezbûr el-Hâc Mahmud'u vasî nasb ve i'tibâr eylediğinde ol dahi vesâyet-i merkūmu kabûl ve merâsimini edâya müte'ahhid olmağın mâ vaka'a bi'ttaleb ketb olundu." denilmektedir. Bkz. İstanbul Kadı Sicilleri Bab Mahkemesi 46
} 
Hüsam Bey mahallesinde oturan Mehmed Çelebi b. Süleyman gibi "Ben işbu sene-i mübârekede hacc-ı şerîfe âzim ve ziyâret-i Ravza-i mutahharaya câzim olmağla eğer ol tarîk-i sa'âdet-feyzde bi iznillâhi te'âlâ kazâ-i nahb ve likā-i Rab müyesser olursa cemî̀ terekem kabz olunup sülüsünden ba'de't-techîz ve't-tekfîn bin akçe iskāt-ı salât için fukarâya verile ve üç sâlih kimesneler rûhum için birer hatm-i şerîf tilâvet edip anlara birer altın verile ve bin iki yüz akçe ile ta'âm tabh olunup fukarâya it'âm oluna ve bin akçe ile bir Mushaf-ı şerîf istihdâ olunup vakf ve mahallemizde vâki' Sunullah Efendi'nin câmi'-i şerîfinde vaz' oluna ve zevcem Fâtıma bt. Abdullah nâm hâtunun zimmetinde mütekarrir ve ma'kūdun-aleyh olan dört bin akçe mehr-i müecceli kendiye teslîm oluna ve sülüs-i mezbûrdan fazla kalırsa fukarâya tevzî‘ oluna ve bâkī kalan sülüsândan mezbûre Fâtıma Hâtun rub' hissesini aldıkdan sonra selâse-i erbâ'ını karye-i mezbûrede sâkin li ebeveyn ammilerim evlâdı Halil ve İhsan ve Zülfi'ye ve li ebeveyn dayım İbrahim b. Cafer'e irsâl ve îsâl oluna" şeklinde terekesinin sülüs kısmıyla gerçekleștirdiği vasiyeti oldukça ayrıntılı olan örnekler de söz konusudur. ${ }^{27}$

İkinci tür vasiyetler ise doğrudan hac ibadetiyle ilgilidir. Arzulamasına rağmen bu ibadetini bizzat yerine getirememiş Müslümanlar "hac vasiyetinde" bulunabiliyorlardı. Yeterli miktarda mala sahip olduğu hâlde, hastalık-yaşlılık gibi çeşitli sebeplerden ötürü hac yolculuğunu yapamayacak durumdaki Müslümanlar, ölüme bağlı olarak, bedelleri terekelerinden karşılanmak üzere vasiyetlerini kaleme aldırıyorlardı. Böylece vekilleri vasıtasıyla da olsa hac görevlerini ifa etmek arzu ediyorlardı. Hac vasiyeti için harcanacak meblâğ, vasiyet sahibinin ölümüyle terekesinden karşılanacağından vârisleri de ilgilendirmekteydi. Terekenin üçte birini aşması hâlinde vasiyeti onaylamayabilirlerdi yahut vasiyetin sihhatine yönelik itirazlarda bulunabilirlerdi. Örneğin, kadı sicillerinde daha fazla görülen durum, vârisler vasiyeti inkâr etmeleridir. $\mathrm{Bu}$ durumda vasiyeti yerine getirmek üzere tayin edilmiş vasiler şahitler veya diğer deliller ile vasiyeti ispat etmek durumunda kalırlardı. ${ }^{28} \mathrm{Bu}$ sebeple hacca gidemeyenler, vasiyetinin yerine getirilmesi için

Numaralı Sicil (H. 1096 - 1097 / M. 1685 - 1686), (haz. Sabri Atay vd), Türkiye Diyanet Vakfı İslâm Araştırmaları Merkezi (İSAM), İstanbul 2011, s. 137, (hüküm.no. 102).

27 İstanbul Kadı Sicilleri Bab Mahkemesi 46 Numaralı Sicil (H. 1096 - 1097 / M. 1685 1686), s. 255,( hk. no. 264).

28 İstanbul Kadi Sicilleri Galata Mahkemesi 37 Numaralı Sicil (H. 1022 - 1024 / M. 1613 - 1615). haz. Rasim Erol vd., Türkiye Diyanet Vakfı İslâm Araştırmaları Merkezi (İSAM), İstanbul 2012, s. 162 (hk. no. 176) 
kurdukları para vakıflarının vakfiyesinde vekaleten hacca göndermeyi bir şart olarak zikrediyorlardı. ${ }^{29}$ Tabii olarak vasiyet gereği vekâleten hacca gönderileceklerle ilgili "salih, mütedeyyin vera sahibi haccin menasikini bilen" gibi sifat ve tezkiye ifadelerinin kayıtlarda yer alması anlaşılır bir durumdur. ${ }^{30}$

Hac bedelleriyle ilgili olarak öncelikle belirtmek gerekir ki sicillerdeki vasiyetlerde zikredilen meblağlar birbirinden farklıdır. Diğer bir ifadeyle belli bir tarihte hac ibadeti için ayrılması gereken muayyen bir bedel söz konusu değildir. Kayıtlarda yer alan rakamlar kişilerin maddi durumuyla doğrudan ilgili görünmektedir. Varlık sahibi insanların bedel olarak yüksek bir meblağ vasiyet etmesi, orta hâlli bir Müslüman'ın ise makul bir bedel belirlemesi anlaşılır bir durumdur. Sabit bir değer söz konusu olmamakla birlikte bedel-i hac olarak vasiyetlerde yer alan rakamlar dönemin sosyo-ekonomik durumuyla ilgili bir fikir vermektedir.

Mahkeme kayitlarında bedel-i hac olarak zikredilen meblağların Osmanlı para tarihi açısından anlamlı bir tarafı da bulunmaktadır. Hac vasiyetlerinde kullanılan para birimleri yüzyıllara göre farklılık göstermektedir. Vasiyetlerdeki para birimleri Osmanlı toplumunda dönem dönem hangi para birimlerinin ne düzeyde hangi yaygınlıkla ve nerelerde kullanıldığı konusuna katkı sağlayabilmektedir. 16 ve 17 . asırlarda kaleme alınmış hac vasiyetlerinde bedel tutarını ifade etmek için yaygın olarak akçe tercih edilmiştir.18. asra yakın dönemlerde Hollanda parası olan esedî kuruş da kullanılırken 1703 yılından itibaren, bu tarihte darbedilmeye başlanacak kuruşun hac vasiyetlerinde yaygınlığı söz konusudur. ${ }^{31}$

16. asırdan 18. asra kadar vasiyetlerde yaygın olarak akçe türünde zikredilen hac bedelleri arasında dikkat çekici farklar bulunmaktadır. İstikrarlı şekilde yükselen hac bedelleri bu yönüyle

\footnotetext{
29 Ístanbul Kadı Sicilleri Rumeli Sadareti Mahkemesi 21 Numaralı Sicil (H. 10021003/M. 1594-1595), haz. Rasim Erol vd. Türkiye Diyanet Vakfı İslâm Araştırmaları Merkezi (İSAM), İstanbul 2011, s. 228 (hk.no.245,

30 Örnekler için bkz. İstanbul Kadı Sicilleri Rumeli Sadareti Mahkemesi 21 Numaralı Sicil (H. 1002-1003/M. 1594-1595), s. 225, (hk. no. 245); s. 302 (hk. no. 327).

31 Akçe ve kuruşların yanı sıra erken dönem vasiyetlerde görülen (bkz. Uzunçarşılı, "Sultan İkinci Murad'ın Vasiyetnâmesi" s. 2) Floransa florini nadiren de olsa bazı hac vasiyetlerinde bedel olarak yer almıştır. Vasiyyeti yapan Donanma-yı Hümâyûn seferine katılıp Koron kasabasında vefat eden Hasan Kapudân b. Abdülmennân adlı bir denizci olduğu için muhtemelen gelirinden dolayı bu para birimi kayıtta yer almıştı. Bedel için zikredilen rakam 100 flori idi. Bkz Istanbul Kadı Sicilleri Galata Mahkemesi 37 Numaralı Sicil (H. 1022 - 1024 / M. 1613 - 1615) s.162 (hk. no 176).
} 
ekonomide yaşanan değişimleri yansıtmaktadır. Artışın en önemli sebebi, iktisadî-malî alanda yaşanan gelişme ve değişimlerdir. Basitçe ifade etmek gerekirse, paranın değer kaybetmesiyle birlikte, hac yolculuğu ve hac ibadeti için yapılması gereken harcamaların rakamsal ifadesi dönemsel olarak düzenli yükselmiştir. Tağşişler, Amerikan gümüşünün Osmanlı piyasalarına giriși, artan hazine harcamaları, uluslararası ticarette yaşanan değişimler vb. gelişmeler Osmanlı ekonomisini ve malî yapısını etkilediği gibi ${ }^{32}$ bu makalenin konusu olan hac vasiyetlerindeki rakamların dönemsel değişimlerini de ortaya çıkarmıştır.

16. asırda veyahut 18. asırda hacca gitmenin bedeli ne kadardı? Bu soruya ilk olarak örnek vakıalardan hareketle yanıt verebiliriz. Erken tarihli kayıtların birinde H.970/M.1563 yılı için bedel-i hac miktarı 4.800 akçedir.33 16. yüzyılın sonlarında bir vakfiye kaydında zikredilen rakam ise 8.000 akçedir.34 Yine 1591 tarihli bir kayıtta Üsküdarlı bir Müslüman'ın hac için vasiyet ettiği tutar 9.000 akçedir. ${ }^{35}$ H.1012/M.1603 tarihinde Balıkesirli Hayreddin Halife'nin hac için vasiyet ettiği rakam olan 12.000 akçe $\mathrm{e}^{36}, 1614$ tarihli bir muhallefat kaydında da karşımıza çıkmaktadır. ${ }^{371618}$ tarihli bir vasiyette ise, 16.000 akçenin hac bedeli olarak kullanılması istenmektedir. Galata'ya bağlı Tophane semti sakinlerinden bir Müslüman'ın H.1051/M.1641 tarihinde sikke-yi hasene olarak 150 sikkelik (akçe olarak 18.0000 akçe) hac vasiyeti

\footnotetext{
32 Halil Sahillioğlu, Bir Asırlık Para Tarihi 1640-1740 (Basılmamış Doçentlik Tezi ) İstanbul 1965, s. 10-15; Ali Akyıldız, Osmanlı Finans Sisteminde Dönüm Noktası Kağıt Para ve Sosyo Ekonomik Etkileri, Eren Yayıncllı İstanbul 1996, s. 23; Şevket Pamuk, Osmanlı Imparatorluğu'nda Paranın Tarihi, Tarih Vakfı Yurt Yayınları, İstanbul 1999, s.124-130.

33 İstanbul Kadı Sicilleri Balat Mahkemesi 2 Numaralı Sicil (H. 970 - 971 / M. 1563). haz. Mustafa Akman vd., Türkiye Diyanet Vakfı İslâm Araştırmaları Merkezi (İSAM), İstanbul 2011, s. 116 (hk.no.117)

34 İstanbul Kadı Sicilleri Rumeli Sadareti Mahkemesi 21 Numaralı Sicil (H. 10021003/M. 1594-1595), s.225 (hk. no.245).

35 İstanbul Kadı Sicilleri Üsküdar Mahkemesi 84 Numaralı Sicil (H.999-1000/ M.15901591). haz. Rıfat Günalan vd. Türkiye Diyanet Vakfı İslâm Araştırmaları Merkezi (İSAM), İstanbul 2010, s. 607 ( hk.no. 1203

36 Balıkesir ŞS, no.693 s. 144. Osmanlı toplumunda kadınların konu edildiği bir çalışmada belgeye atıfta bulunulmuş ancak rakam belirtilmemiștir. Bkz. Abdülmecit Mutaf, XVII. Yüzyılda Balıkesirli Kadınlar, Dokuz Eylül Üniversitesi SBE, (Basılmamış Doktora Tezi) İzmir 2002, s. 109.

37 İstanbul Kadı Sicilleri Galata Mahkemesi 37 Numaralı Sicil (H. 1022 - 1024 / M. 1613

- 1615 Galata 37/15 Ba
} 
bulunmaktadır. ${ }^{381676}$ tarihli tereke kaydına göre, hac için ayrılan rakam 350 esedî kuruş idi. ${ }^{39}$ H.1126/M.1714 tarihli Kırım mahkeme kaydında hac bedeli olarak tahsis edilen paranın 20.600 akçe olduğu zikredilmektedir. ${ }^{40}$ H.1133/M.1721 tarihli Kıbris sicilinde ise, hac bedeli olarak kayıtlı rakam 60.000 akçedir. ${ }^{41}$ H.1159/M.1746 tarihli yine Kıbrıslı bir Müslüman'ın hac için vasiyet ettiği meblağ 370 kuruş idi.42

\section{Hacıların Yol Güzergâhları ve Hacc İçin Yola Koyulma}

Hac yolları ve menziller ile ilgili pek çok çalışma bulunduğu için ${ }^{43}$ bu makalede sicillerdeki kayıtlara yansıdığı kadarıyla konu üzerinde durulacaktır. Öncelikle belirtmek gerekir ki, yol sistemi açısından Osmanlı Devleti, Anadolu ve Rumeli bölgelerindeki toprakları için sağ, orta ve sol olmak üzere üç ana yol belirlemiştir. Anadolu ve Kafkaslardaki hacılar değişik güzergâhları takip ederek Şam'da buluşurlardı. Şam Osmanlı Devleti'nin karayolu ile yapılan hac ibadetinin mühim bir kavşak noktasıdır. 1708 yılından itibaren Şam valileri emirü'l-hac olarak atanmaya başlayacaktır.44 Rumeli hacıları ise İstanbul üzerinde toplanıp karayolu ile bugün Üsküdar'da Harem olarak bilinen mekânın ilerisinde Ayrılık Çeşmesi'nden hareket ederlerdi. ${ }^{45}$ Örneğin Müzeyrib'de vefat eden Sofyalı el-Hâc Hüseyin b. Ramazan, Sofya-Filibe-Edirne-Çorlu-Silivri ve İstanbul yolunu kullanarak Şam'a vasıl olmuştur.46 İran'la olan sıkıntılı

\footnotetext{
38 İstanbul Kadı Sicilleri Galata Mahkemesi 65 Numaralı Sicil (H. 1051- 1053 / M. 1641 - 1644). haz. Sabri Atay, vd., Türkiye Diyanet Vakfı İslâm Araştırmaları Merkezi (ISAM), İstanbul 2012, s. 46, (hk.no. 13.)

39 İstanbul Kadı Sicilleri İstanbul Mahkemesi 18 Numaralı Sicil (H. 1086- 1087 / M. 1675 - 1676). haz. Salih kahrıman vd., Türkiye Diyanet Vakfı İslâm Araştırmaları Merkezi (ISAM), İstanbul 2010, s. 199 ( hk.no. 158)

40 Metin Bilal, 45 No'lu Kırım Kadı Sicilinin Trankripsiyonu ve Değerlendirilmesi, Karadeniz Teknik Ü. SBE, (Yayınlanmamış Y. Lisan Tezi) Trabzon 2015, s.102.

${ }^{41}$ Kıbris ŞS no. 11 , s. 4

42 Kıbris ŞS, no. 17, s. 23.

4316 numaralı dipnota bkz.

${ }^{44}$ Adil Erken, XVIII. Yüzyıl Osmanlı Şam Valilerinin Emirül-Hacc Olarak Hizmetleri, Kocatepe Üniversitesi SBE, (Basılmamış Doktora Tezi) Afyonkarahisar 2017, s. 1828.

${ }^{45}$ Hac güzergâhları için kaleme alınan eserlerin çoğu yol başlangıcı olarak Üsküdar'ı vermektedir. Osmanlı dönemi Kırım ve Balkanlar üzerinden pek çok insanın hacca gittiği düşünüldügünde bu yollar için de ayrıca araştırmalara ihtiyaç vardır. Konuyla örnek çalışma için bkz. Aytekin Yılmaz, Osmanlı Dönemi Edirne - Mekke Hac Yolu H. 1008-1214 / 1600-1800. Marmara Üniversitesi SBE (Basılmamış Y. Lisans Tezi) İstanbul 2001, s. 36-40.

${ }^{46}$ Sofya ŞS, no.12 s. 32.
} 
durumdan dolayı Kefe ve Özi limanları, Kırım bölgesindeki hacılar başta olmak üzere Orta Asya hanlıklarında yaşayan Müslümanların hac için kullandıkları önemli bir güzergah idi. Burada toplanan hacılar deniz yoluyla İstanbul'a gelir, Şam kervanına dahil olurlardı. ${ }^{47}$ Aynı şekilde Kafkasya'da yaşayan Müslümanlar Üsküdar'da hac kervanına katılırlardı. ${ }^{48}$

Mahkeme kayıtlarının bize gösterdiği bașka bir rota da deniz yoludur. 1869 yllında Süveyş Kanalı'nın işlerlik kazanmasından sonra bu yol daha revaç bulmuştur. H.1163/M.1750 tarihli Sofya sicilinde yer alan kayda göre, Kahire yakınlarında Bulak'ta vefat eden Sofyalı Hacı Ali b. Süleyman adlı kişi deniz yolunu kullanmıştır. ${ }^{49}$ Yine 1743 tarihli bir kayıtta Bosna valisinin hac dönüşü gemisinin denizde battı̆̆ından bahsedilmektedir. ${ }^{50}$ Hac güzergâhı açısından önemli bir husus Kıbrıs ve Rodos gibi adalarda yaşayan Müslümanların takip ettikleri rotadır. Bunların yukarıda bahsi geçen karayolu güzergâhlarını kullanmaları mümkün gözükmemektedir. Vefat edilen mekânlardan hareketle deniz yolu güzergahını yani Mısır üzerinden kutsal beldelere ulaştıkları görülmektedir. Mesela Kıbrıs sicillerinde yer alan bir kayıtta aslen Rizeli olup Kıbrıslı hacı Hacı Hasan bin Hüseyin adlı Müslümanın vefat yeri olarak Kahire zikredilmektedir. ${ }^{51}$

Herhangi bir devlet görevi bulunmayan siradan Osmanlıların hac yolculuğu için resmî makamlardan izin almaları gerektiğine dair bir mahkeme kaydına rastlamadık. Yapılan çalışmalarda da hac yolculuğu için izin gerektiğine ilişkin bir bilgi bulunmamaktadır. Bilakis resmî kayıtlarda, örneğin hacca giden bazı Müslüman kadınlara engel çıkarmak isteyenlere karşı görevlilerin uyarılması ve hacıların yolculuğu için gerekli tedbirleri alması gibi ${ }^{52}$ Osmanlı Devleti'nin hac yolculuğunu güvenli ve kolaylaştırıcı rol aldığı görülmektedir. Sıradan insanların aksine resmî görevi bulunan,

\footnotetext{
47 Özcan. a.g.m., s.405,. Bu bölgedeki Müslümanların hac yolculukları Osmanlı’nın sonuna kadar zor şartlarda gerçekleşmiştir. Trenlerin ve vapurların yol için kullanılır olmasına rağmen siyasi șartların ve iklim şartların değișik olması haccın zorluğu dönemin hac seyahatnamelerinde ifade edilmiştir. Bkz. Abdullah Gündoğdu, "Pilgirim and Traveler: Hajnamas from the Volga-Ural Region", Proceeding of the Third International Symposium on Islamic Civilation in Volga-Ural Region, Ufa 2008, s. 137-144.

48 Üsküdar ŞS, no.412, vr.39a.

${ }^{49}$ Sofya ȘS, no.17 s. 15.

50 İstanbul Ahkâm Defterleri, İstanbul"da Sosyal Hayat, (haz. A. Tabakoğlu v.d.), İstanbul 1997, I,120.

51 Kıbris ȘS, no.14 s.77

52İstanbul Ahkâm Defterleri, İstanbul"da Sosyal Hayat, I,84, 238.
} 
Osmanlıların tanımlamasıyla askerî sınıftan olan kişilerin, hacca gitmek için izin almaları gerekiyordu. ${ }^{53}$ Görevdeyken hac izni isteyen askerî sınıf mensupları hakkında tahkikat yapılırdı. Şaibeli bir durum söz konusuysa, örneğin kişinin kaçması, isyan etmesi ihtimali var ise hac izni çıkmazdı. ${ }^{54}$ İzin talepleri olumlu karşılanan görevliler yerine bir vekil bırakarak hac farizası için yola koyulurlardı.

Osmanlıda hacca giden her Müslüman genel kaide olarak masraflarını kendisi karşılardı. ${ }^{55}$ Devlet yol güvenliğini sağlamak, ulaşım altyapı hizmetlerini sunmak gibi görevleri üstlenirken ${ }^{56}$ hacılar da kendilerinin şahsî yol harcamalarını, örneğin yolculukta kullanılan gemilerin yahut binek hayvanlarının ücretlerini karşılarlardı. Bazı hacıların yol güzergâhında satın aldıkları atlar dolayısıyla davalık oldukları görülmektedir.57 Hac yolculuğu esnasında parası kalmayan hacıların birbirlerinden borç almaları mutat bir durumdu. Alınan borçlar muhtemelen düzenli olarak ödeniyordu, ancak bazı örneklerde ödenmeyen borçtan dolayı davalık olmuş kişilere de rastlanıyordu. El-Hâc Ahmed adındaki Üsküdarlı bir hacı H.1154 senesinde seksen kuruş borç verdiği esSeyyid Mustafa'nın oğlundan alacağını tahsil için kadıya başvurmuştu. ${ }^{58} \mathrm{Bu}$ örnekte olduğu gibi taraflardan birinin ölümü meselenin mahkemeye taşınmasında önemli sebeplerden biridir. Parasal ilişkiler genelde aynı şehirden yola çıkmış, hemşehri hacılar arasında olmaktaydı. Kırım sicilinde yer alan bir kayda göre el-Hac Ali adlı bir Müslüman'ın, hac esnasında ismi zikredilmeyen bir Müslüman'dan 32,5 arslanî kuruş borç aldığg ifade edilmektedir. ${ }^{59}$

\footnotetext{
53 İstanbul 18, s.160 hk.no. 145.

54 BOA, A.DVNSMHM.d. 27/218 11-08-983/ 15 Kasım 1575.

55 Faroqhi, Hacllar ve Sultanlar s. 45 .

56 Hac yolu üzerinde bulunan Konya civarındaki Kadıhanı'nın suyollarının tamiri için icap eden masraflar, Karaman mütesellimine yazılan hükümde borcu olan insanlardan tahsil edilerek gerekli tamiratın yapılması istenmiştir. BOA, AE, SMHDI, 77/5099. Yine yolculuk esnasında durumu kötüleşen hacılara bazı yardımlar yapılmaktadır. Hac kervanının sağ salim gidip gelmesini sağlayan görevliler vardı. Bunların maaşları, harcamaları devlet bütçesinden, Kilâr-ı Has-ı Hacc-ı Şerif adındaki bir daireden sağlanmaktaydı. Bkz. Faroqhi, Hacılar ve Sultanlar s.45.

57 Mustafa Itri Küçükoğlu, Üsküdar Mahkemesi 510 Numaralı Şer'iyye Sicilinin Transkripsiyon Ve Değerlendirmesi: 1782-1783 (H. 1196-1197),Harran Üniversitesi SBE, (Basılmamış Y. Lisans Tezi) Şanlıurfa 2015, 510 Üsküdar s. 363.

58 Deniz Akkaya, Üsküdar Kadılığı 420 Numaralı Şeriyye Sicili Defteri 1159-1160/ 1747-1748), Marmara Üniversitesi S.B.E., 1999, s.135 (Hüküm no.265).

${ }^{59}$ Dilek Çelik, 67 A 90 Nolu Ve 1017-1022(1608-1613) Tarihli Kırım Hanlığı Kadıasker Defteri (Tahlil Ve Transkripsiyon) Sakarya Üniversitesi SBE (Basılmamış Y. Lisans Tezi) Sakarya 2011, s.178 (hk. no. 313
} 
Hacca gitmenin maddi bir bedeli olduğu için bu ibadeti yerine getireceklerin mali açıdan kendilerini hazırlamaları gerekiyordu. Hac mevsimi yaklaştığında yeterli parayı toplayamayan insanlar, sahip oldukları gayrimenkulleri satıp hac farizası için gerekli parayı denkleştirme yoluna gidiyorlardı. İstanbul merkezli düşündüğümüzde Osmanlı dönemi karayolu ile haccın Receb ayında 60 başlamasından dolayı, hac için mülk satışlarının Receb ayında veya öncesi birkaç ayda yapılması gerekmektedir. Konuyla ilgili örneklerden birinde Üsküdar/Debbağlar Mahallesi'nden el-Hâc Mehmed b. Ömer adlı bir kimse hacca gitmek için Davutpaşa Mahallesi'ndeki 300 kuruş değerindeki saraç dükkânını aynı mesleği icra eden İbrahim'e 25 Cemaziyelâhir 1132/4 Mayıs 1720 tarihinde satmıştır. ${ }^{61}$ Hacc için mülk satışları yeri geldiğinde aynı şehirde yaşayan başka din mensuplarına da olabiliyordu. Nitekim 29 Receb 1130/28 Haziran 1718 tarihli mahkeme kaydına göre, hacca gitmeye niyetlenen Üsküdar Aşçıbaşı Mahallesi'nden el-Hâc Abdullah b. Abdullah adlı kimse bağlarıyla ünlü Ivaz Fakih'teki on yedi dönüm 460 kuruş değerindeki bağını Yakob v. David adlı bir gayrimüslime satmıştır. ${ }^{62}$

Hacca gidecek kimselerden bazılarının eşlerine ve yakın akrabalarına mülk sattıkları da mahkeme kayıtlarından anlaşılmaktadır. H.1132 yılında aslen Karahisar-ı Şarki'den (Şebinkarahisar) olan Bekârzâde namıyla tanınan Seyyid Musa Çelebi b. Seyyid Mustafa, Şebinkarahisar'daki evini eşi Aişe'ye 600 kuruşa satmıştı. ${ }^{63}$ Aynı sene Üsküdar/Aşçıbaşı Mahallesi'nden Mehmed Beşe b. İbrahim ise, kayınvalidesi Emine bt. Himmet'e Bulgurlu'da bulunan diğer yarısı eși Fatıma'ya ait olan bağdaki yarı hissesini 200 kuruşa satmıştı. ${ }^{64}$ Yakın akrabalar arasında gerçekleşen bu satışların ihtiyaca binaen mi yoksa hac yolunda vefat etme durumunda mülklerin eşine veya tercih ettiği yakın akrabasına kalması için mi yapıldığını bilemiyoruz.

Köleler hakkında mahkemeye intikal eden davaların bir kısmı hacca giden insanların yanlarında götürdükleri kölelerin kaçması

\footnotetext{
${ }^{60}$ H.1194/m. 1780 tarihli anomim adlı hac menzilleriyle ilgili eserin derkenârında Üsküdar'dan hareket günü olarak 22 Recceb 1194 tarihi verilmiştir. Bkz. Menazilil'IHacc ve Mesafetil'I-Fecc li'I-Acc ve's-Secc min Gayn Lecc, Süleymaniye Kütüphanesi , Așir Efendi 241/2'den naklen. A. Latif Armağan, a.g.m, s.83.

61 Üsküdar ŞS,364 50a, 55a, 59a.

62 Üsküdar ȘS, 362,45a, Nevzat Erkan, a.g.e., s.86.

63 Üsküdar \$̦, no.364, vr.36b.

64 Üsküdar ȘS, no. 364, vr.58a.
} 
sebebiyle açılmış davalardır. Hac yolculuğuna kölesiyle çıkan Ahıskalı Bayraktar Musa'nın Gürcü asıllı kölesi İzmit taraflarında firar etmiştir. Üsküdar çorbacısının marifetiyle kaçan köle yakalanmış, efendisine teslim edilmiştir. Bayraktar Musa tekrar yanına aldığı kölesiyle hac yolculuğuna devam etmiştir.65

\section{Hac Dönüşü Karşılaşılan Problemler}

Meşakkatli ve uzun süren bir yolculuk sonrası hac farizasını yerine getirmiş olarak el-Hâc unvanıla şehirlerine/köylerine dönmüş kişiler karşılaştıkları bazı meseleleri dava konusu olarak mahkemeye taşıyabiliyorlardı. Örneğin, hacca giderken yerlerine vekil olarak bıraktığı kişilerin usulsüz davranışları hacıları zor duruma sokuyor, sorunun halli için kadıya başvurmaları gerekiyordu. Kıbris adasından Hacı İbrahim bin Osman, hacca giderken Tuzla'ya bağlı Çite köyündeki vakıf çiftliğini işletmek üzere kardeşini nazır tayin etmişti. Hac dönüşü mahsulatın usulsüz harcanmasından dolayı davacı olmuş, ancak arabulucular vasıtasıyla kardeşiyle 120 kuruşa sulh etmişti. ${ }^{66}$ H.1139/M.1727 yllında Üsküp'te yaşanan bir hadisede, Lütfullah b. Hacı Mehmed, Gazi İsa Bey Vakfında mescid imamlığı ve hatiplik gibi görevler kendi uhdesindeyken vefat eder. Mutasarrıf olarak üzerinde bulunan bu görevler oğulları Ebubekir Halife ve Hacı Mehmed Halife'ye eşit olarak intikal etmesi gerekirken biraderi Mehmed Halife'nin hacda olmasını firsat bilen Ebubekir Halife bütün görevleri kendi üzerine alır. Hac dönüşü kadıya başvuran Mehmed Halife yapılan görevlendirmenin haksız olduğunu iddia ederek yarısının kendisine verilmesini talep eder. Bu talebi haklı bulan Üsküp Kadısı İmam-zâde Mustafa Efendi bu cihetlerin yarı hissesinin Hacı Mehmed Halife'ye tevcih edilmesine karar verir.67

Hac öncesi halledilmesi gereken borç-alacak gibi kimi meselelerin çözümü hac sonrasına kalabiliyordu. H.1119/M.1708 tarihli mahkeme kaydına göre, Üsküdar Tenbel el-Hâc Mehmed Mahallesi'nden el-Hâc Süleyman Çelebi b. Mehmed iki sene önce hacca giderken Mardiros ve Kurik adlı Ermenilerden alacağı olan 144 kuruşu tahsil etmesi için Mahmud Beşe'ye vekalet vermişti. Hac dönüşü paranın tamamını vermediği gerekçesiyle davacı olmuş, mahkeme de el-Hâc Süleyman Çelebi'ye bağına yapılan tımar

\footnotetext{
65 Üsküdar ŞS; no.412, vr.39a.

${ }^{66}$ Kibris ŞS, no. 10 s. 24

67 BOA, A. DVNSRSK. D.78, v.487'den naklen Hasan Telli, Osmanlı Dönemi Üsküp Vakıfları, Ankara Üniversitesi SBE, (Basılmamış Doktora Tezi) Ankara 2018. s. 44.
} 
masrafları çıkarıldıktan sonra vekil konumundaki Mahmud Beşe'nin 14 kuruş ödemesine hükmetmiştir.68

Karşılaşılan bir başka sıkıntı hacıların ölmediği hâlde vefat etti zannıyla yapılan yanlışlıklara dairdir. Hacca giden kimse devlet görevlisi ise öldüğü zannıyla yerine asaleten biri atandığında hac dönüşü tekrar eski vazifesine atanmak için fazlasıyla uğraşması gerekiyordu. Nitekim 15 Rebîulâhir 1091/15 Mayıs 1680 tarihli bir kayıtta, Kasımpaşa Tersane Camii vaizi Mehmed Efendi'nin, hac dönüşü kendi öldü denilerek yerine Şeyh Mehmed adında bir başka vaiz atanmasından dolayı eski hizmet yerine atanması için arzda bulunması gerekmiști. ${ }^{69}$ Benzer bir hadise H.1134/M.1722 yılında Afyon Karahisar'da yaşanmıştır. Hüseyin adlı tımar sahibinin tasarruf hakkı, hacda öldü zannıyla, oğlu Kasım'a devredilmişti. Payitahta yazılan arzda tımar sahibinin hayatta olduğu için oğlunun elinden alınması istenmekteydi. ${ }^{70}$

Vefat etmediği sonradan anlaşılan kişiler haklarında böyle davranılmasının sebeplerini belgelerdeki ifadelerden çıkarmak mümkündür. Yanlış bir haberin yayılması, hac dönüşünün gecikmesi böyle bir zanna sebep olabiliyordu. Nitekim 25 Cemaziyelâhir 1102/26Mart 1691 tarihinde tutulmuş dava kaydında71 İstanbul'da Murad Paşa Mahallesi'nde yaşayan Sâime bt. Abdullah adlı bir hacı kadın, Çerkes Ahmed Paşa'nın azatlısı Aişe bt. Abdullah'dan hibesinden dönmesine rağmen kendisine ait mülkün geri verilmemesi sebebiyle davacı olmuştu. Ahmed Paşa Saime'nin hacda öldüğünü düşünerek daha önce vazgeçtiği hibe evi Aişe'ye teslim etmişti. Mahkemenin haklı bulduğu Saime Hanım'ın vefat etmiş olduğuna dair haberin yayılması muhtemel bir gecikmeden dolayı olmuş olabilir. Zira, kayıt tarihinden hareketle İstanbul hacılarının Receb ayında yola çıkıp Ramazan ayını Şam'da geçirmelerinden dolayı gidiş yolunda bir aylık gecikme yaşanırken dönüş yolu daha kısa sürdüğü için dava kaydından en az iki ay önce yani Rebîulevvel ayında İstanbul'a ulaşması gerekiyordu.

Hac Yolunda Vefat ve Yakını Hacda Vefat Eden İnsanların Karşılaştıkları Zorluklar

\footnotetext{
68 Üsküdar ŞS, no.336, vr.40b.

${ }^{69} \mathrm{BOA}$, İE, EV, 5/567.

70 BOA, İE, AS, 64/5787.

71 Ístanbul kadı sicilleri Bab mahkemesi 54 numaralı sicil (H. 1102 / M. 1691), (haz. Hüseyin Kılıç v.d.) Türkiye Diyanet Vakfı İslâm Araştırmaları Merkezi (İSAM), İstanbul 2011, s. 369 (Hüküm no. 450).
} 
Osmanlı döneminde; İstanbul merkezli düşündüğümüzde yaklaşık 8-9 ay süren, Orta Asya, Kırım ve Balkanlarda yaşayan Müslümanlar açısından baktığımızda ise neredeyse yılın tamamını kaplayan hac yolculuğu, ağır yol şartları, iklim ve coğrafî koşullar neticesinde bazı yolcular için hayatlarının son yolculuğu anlamına geliyordu. Özellikle yaşlı, güçsüz ve hastaların bu yolculukta vefat etmeleri daha yüksek bir ihtimaldi.72 İklim şartlarının yanı sıra salgın hastalıklar ${ }^{73}$ sel felaketi gibi doğal afetler hacca giden Müslümanların vefatına sebep olabiliyordu..$^{74}$

Hac yolunda Şam'dan sonraki süreçte bedevi kabilelerinin baskınlarının yanı sıra ${ }^{75}$ Şam'a varıncaya kadarki yol güzergâhında eşkıya saldırıları hacıların canlarına ve mallarına zarar vermekteydi. Nitekim 1158 senesinde Erzurum ve Gümüşhane'den çlkan hacı adayları Çemişgezek taraflarında eşkıya baskınına uğramış ve birçoğu vefat etmiştir. ${ }^{76}$

Mahkeme kayıtlarında "tarik-i hacda vefat eden" ifadeleriyle geçen hac yolculuğunda vuku bulan ölümlere ilişkin sınırlı bilgi

\footnotetext{
${ }^{72}$ Son devir Osmanlı münevverlerinden Eyüp Sabri Paşa, Haremeyn ile ilgili eserinde "Hicaz'a gideceklere nasihat" bașlığı altında hac yolculuğunda iklim değișikliklerinin hacıların vefatına ve mübarek beldeyi ziyaret hususunda aciz bıraktı̆̆ını söyleyip bununla ilgili nasihatlerde bulunmaktadır. Bkz. Eyüp Sabri Paşa (1308/1890), Mir'atü'l-Haremeyn=Haremeyn Tarihi haz. Ömer Faruk Can, Zehra Can Yazma Eserler Kurumu Başkanlığı, İstanbul 2018, I,267-270;

731846 senesinde aralarında Osmanlı musikisinin zirve isimlerinden İsmail Dede Efendi'nin bulunduğu hacda yaklaşık 5000 kişi kolera salgını sebebiyle vefat etmiş ve ölen hacıların muhallefat kayıtları Mekke Kadılı̆̆ı tarafından tek tek kayda geçirilmiștir. Bkz. Talip Mert, "Arşiv Belgelerine Göre Dede Efendi'nin Veda Haccl" Türk Edebiyatı Aylık Fikir ve Sanat Dergisi, Aralık 2009, CDXXXIV, 10-14;

74 Şeyh Ahmed el-Bedirî Hallak, Berber Bedrinin Günlügü:1741-1762: Osmanlı Taşrasına İlişkin Olaylar nşr. Ahmet İzzet Abdülkerim trc. Hasan Yüksel Akçağ Yayınları, Ankara 1995, s 26,177.

75 Hac yolculuğu için en zor bölüm Şam- Mekke arasında yer yolculuk idi. Burada bedevi kabilelerin hac kervanlarına saldırmaları Devleti temsilen Şam valilerini bir dizi önlem almaya itiyordu. Güzergah üzerindeki kalelerin tahkimi su temini gibi çalışmalara ilave olarak, hac için gönderilen sürrenin yanı sıra urban tahsisatı adı altında bölgede yaşayan urban tahsisatı denilen ödemeler yapılmaktaydı. (Açılamalar için bkz. Kurşun, s. 289). Alınan önlemlere rağmen hacıların can ve mallarına yönelik saldırılar olmaktaydı. Özellikle 1701 yılında 'Ulâ menzilinde eşkıya baskını sonucu 30.000 hacı vefat etmiști. Bkz. Bakkalzâde Defterdar Sarı Mehmed Paşa, Zübde-i Vekaiyat,(Tahlil ve Metin) 1066-1116/1656-1704), (haz. Abdülkadir Özcan) TTK, Ankara 1995, s. 716; Atalar, Sürre-i Hümayun, s. 139, İzzet Sak, Cemal Çetin, a.g.m. s. 205.

76 Divân-ı Hümâyûn Sicilleri Diyarbekir Ahkâm Defterleri (H1155-1167 / M. 17421754) haz. Ahmet Zeki İzgöer Dicle Üniversitesi İlahiyat Fakültesi Diyarbakır 2016, I,166-167.
} 
verilmektedir. Örneğin ölüm sebebi ve zamanına dair bilgilere bu kayıtlarda ulaşmak genellikle mümkün değildir. Hacıların vefat ettiği mekanlar konusunda çok az kayıtta bilgi yer almaktadır. Konuyla ilgili Balıkesir özelinde yapılan bir çalışmada, hac yolunda vefat eden insanların Şam, Cidde ve Mekke'de vefat ettikleri belirtilmektedir. ${ }^{77}$ Bizim incelediğimiz sicillerde Şam'a ilaveten ${ }^{78}$ Medine-i Münevvere ${ }^{79}$ Şam-Mekke güzergahında bulunan Müzeyrib80, Kahire-Mekke arasında yer alan Bulak $^{81}$, Kahire ${ }^{82}$, Bedr-i Huneyn ${ }^{83}$, Karaman Ereğlisi84, Aynü'l-Kassab ${ }^{85}$, Akdeniz ${ }^{86}$ ve Akabebaş1 $^{87}$ da vefat bölgeleri arasındaydı.

Hac yolculuğunda canı ve malı korumanın zorluğu yanında bir de hac yolunda vefat etme ihtimali vardı. Vefat eden kişinin vârisi olmazsa malları hazineye devredilmekteydi. Özellikle geride bıraktıkları mirasçıların haklarını korumak üzere hacı adayları vasi tayin etmekteydiler. Kahire'den yola çıkan hac kervanında şayet vekil/vasi bırakmadıysa ölen kişinin malları beytülmale devredilmekteydi. Şam'dan giden hac kervanında da aynı kural geçerli ancak Şam kervanında aynı köy veya kasabadan bir arkadaşı vefat eden kişinin arkadaşının geride bıraktığı mallarının sorumluluğunu üstlenebildiği belirtilmektedir. ${ }^{88}$

Osmanlı uygulamasında kişilerin vefatıyla tereke kayıtları belli şartlar ve prensipler çerçevesinde tutulmakta ve tereke mirasçılar arasında taksim edilmekteydi. Bu yönüyle bakıldığında hac

\footnotetext{
77 Serdar Genç, a.g.m., s. 313.

78 Üsküdar ŞS, no, 363 vr.128a.

79 Ístanbul Kadı Sicilleri Bab Mahkemesi 46 Numaralı Sicil (H. 1096 - 1097 / M. 1685 1686), s. 151, (Hüküm no..117.

80 Balat 2 s. 216. Hk.no. 316, Sofya 12 Nolu sicil,

81 Sofya ŞS, no. 12 . S34.

82 Kıbrıs ŞS no.14 s.77.

83 İstanbul Kadı Sicilleri Bab Mahkemesi 46 Numaralı Sicil (H. 1096 - 1097 / M. 1685 1686), s. 173,( Hüküm.no. 145).

84 İstanbul Kadı Sicilleri Bab Mahkemesi 46 Numaralı Sicil (H. 1096 - 1097 / M. 1685 1686), s.520(Hüküm no, 625.

85 İstanbul Kadı Sicilleri Bab Mahkemesi 46 Numaralı Sicil (H. 1096 - 1097 / M. 1685 1686), s. 81 hk. No. 44.

86 Galata 32 s. 176 , hk.no

87 Üsküdar ŞS, no.378, vr.10b

88 Faroqhi, Hacılar ve Sultanlar s.48; Savaş dönemleri dışında İranlı şiilerin hacca gitmlerine için herhangi bir engel çıkarılmamış, hac yolunda vefat eden şii hacıların muhallefatı Osmanlı tebaasına nasıl muamele yapılıyorsa aynen uygulanmıştır. 1712 yılında Acem hacının muhallefatının varislerine gönderilmemesi sıkıntıya sebep olmuş, konuyla ilgili görevlilerin cezalandırılması emredilmiştir. Bkz. BOA, A. DVN. MHM. d., 119/833'den naklen, Erken, a.g.e., s. 178.
} 
yolunda vefat eden kimselerin iki türlü tereke kaydının tutulduğunu söylemek mümkündür. Birincisi yolda vefat ettikleri zaman tutulan tereke defterleri idi. Bunlar daha çok yol için lazım olan giyim kuşam ve binek eşyalarından oluşmaktaydı. Bunların yanında misvak ve Şam kuşağı gibi hacda veya hac yolunda alınmış eşyalar da mevcut olabilirdi. Bunlar beytülmal emini tarafından vefat eden kişinin vâsîyi muhtârlarına teslim ediliyordu. ${ }^{89}$ İkinci tür kayıt ise, vefat haberinin hacının yaşadığı yere ulaşmasından sonra memleketinde tutulan, hac yolunda tutulan terekede yer almayan muhtemelen mirasının büyük kısmını içeren tereke defteridir. ${ }^{90}$ Bunlar içinde yolda vasî-yi muhtâr olarak atanan kimselerin getirdiği malların dâhil olduğu tereke kayıtları olduğu gibi ${ }^{91}$, hac yolundaki malların yer almadığı, sadece yaşadığı şehirdeki mallardan müteşekkil terekeler de bulunmaktadır. 92

Tereke kayıtlarında dikkat çeken bir husus ölen hacıların geride bıraktıkları yetimlerdir. Miras taksimi yapılırken yetimlerin haklarının korunması ve işlerinin görülmesi için bir vasi atanmaktaydı. ${ }^{93}$ Tezkiye ifadelerinden anlaşıldığı kadarıyla vasiler ehliyetli ve dürüst insanlar arasından seçilmekteydi. ${ }^{94}$ Vasilerin görevlerini hakkıyla yapıp yapmadıklarını denetlemek ve onlara bir manada rehberlik etmek amacıyla bazen vasi üzerine nazır tayini yapılmaktaydı. Nitekim 1679 yllında Eyüb Sultanlı Hüseyin b. Gülümşah'ın hacda vefat etmesi sonucu küçük oğlu Mustafa için amcası Mustafa vasi tayin edilmiş ve bunun üzerine de mahkeme

\footnotetext{
89 BOA, D. BŞM, MHF.d. 13642 (29 Zilkâde 1100/14 Eylül 1689)

90 Osmanlı sosyal tarihinin önemli belgelerinde olan tereke kayıtları için pek çok çalışma bulunmaktadır. Bu sebeple çalışmaların analizi ve tereke kayıtlarının değerlendirilmesi için bkz. Fatih Bozkurt, Tereke Defterleri ve Osmanlı Maddi Kültüründe Değişim (1785-1875 İstanbul Örneği) Sakarya Üniversitesi SBE, Sakarya 2011, s. 33-35. Tereke defterlerinin kaynak değeri ve tereke çalışmaları hakkında ayrıca bkz. Fatih Bozkurt, "Osmanlı Dönemi Tereke Defterleri ve Tereke Çalışmaları" Türkiye Araştırmaları Literatür Dergisi, sy. 22, 2013, s. 193-229.

${ }^{11}$ Serdar Genç'in incelediği tereke kayıtlarında ihramın yanı sıra Şam Alacası ve Şam Penbesi gibi hac yolunda alınmış malzemeler bulunmaktaydı., Genç a.g.m., s. 313.

92 Örnek için bkz. Sofya ŞS, no.23 s.170.

93 Üsküdar/İstavros (Beylerbeyi) köyünden Ahmed b. Süleyman'ın hac dönüşü Şamda vefat etmesi sonucu yetimin vasîsi olan Ali Beğ b. Hüseyin Üsküdar kadısına gelerek terekesini kaydettirmiști. Bkz. Üsküdar ȘS, no.363, vr.128b-129a.

${ }^{94}$ Açıklamalar için bkz. Fatih Bozkurt, "Yetimi Kolla, Malını Koru! Tereke Defterleri ve Yetim Malları (1785-1875)" Trakya Üniversitesi Edebiyat Fakültesi Dergisi, Cilt: 2, Sayı: 3, Ocak-2012, s. 69-90.
} 
tarafından Nasuh b. İbrahim adlı bir Müslüman nazır tayin edilmiştir. ${ }^{95}$

Devletin yetimler konusunda hassasiyetinden dolayı hac yolunda vefat edenlerin geride bıraktığı yetimlerin hakkının korunması için zaman zaman terekeler uygun bir fiyat buluncaya kadar bekletilirdi. Örneğin 1658 yllında Edirne'den hacca gidip dönüşte vefat eden Şaban Beşe adlı bir Müslüman'ın geride yetimi olduğu için, terekesinde bulunan değerli hac malzemelerinin değerini buluncaya kadar vasilerinin malları muhafaza etmesi istenmiştir. ${ }^{96}$

Vasiler yaşadıkları müddetçe ve vesayetleri altındaki yetimler reşit oluncaya değin hem yetimlerin mallarını koruyorlar hem de onların bakımını üstleniyorlardı. Bunun için yetimin günlük nafaka bedelini kadıya gelip kayıt altına aldırıyorlardı. ${ }^{97}$ Vasinin ölümüyle mallarının mirasçılarına kalması ve bu mallar içinde yetimlerin hakkının iade edilmemesi dava konusu olmaktaydı. Kıbrıs adasında Lefkoşa'nın Ayasofya Mahallesi'nde ikamet eden Abdürrahim Ağa bin Mehmed hac yolunda vefat etmiş, kızı Emine için mahkeme tarafından Mahmud Ağa bin Mehmed Efendi vasi tayin edilmişti. Mahmud Ağa'nın ölümü sonrası Mekke-yi Mükerreme'den gelen hac eşyasının yetimin hakkı olduğu hâlde mal sahibine verilmediği için Emine Hanım davacı olmuş ve Mahmud Ağa kızı Emetullah Hanım ile 60 kuruşa sulh olmuşlardır. ${ }^{98}$

Hac için çlktığı yolda emr-i hak vaki olup vefat eden Müslümanların mirasçıları da değişik meselelerle yüzleşmek zorunda kalmıştır. Vefat sonrası karşılaşılan ilk sıkıntı miras ile ilgili hadiselerdir. Öncelikle hacı yakınları vefat haberini aldıktan sonra, ölen hacının yanında bulunan emvali alabilmek için yola koyulmak zorunda kalabiliyorlardı. Rize'den hac için yola çıkan Hasan bin Hüseyin Kahire'de vefat etmişti. Mirasçıları hacının terekesini elinde bulunduran ve Rizeli olan Zeynî Mustafa bin Mehmed'den alabilmek için Kıbrıs'a gelmişler ancak Zeynî Mustafa'nın vefat etmiş olması sebebiyle terekeyi zabteden beytülmâl emini el-Hâc Osman bin

\footnotetext{
95 Eyüb 90, s. 582, hk. No. 744.

96 Edirne Şer'iyye Sicili, no.42 s.4'den aktaran Barkan, a.g.m s. 401-402; Yetimlerin hakkını koruma konusunda gösterilen hassasiyetin yanı sıra belli bir maișetle çalıșan resmi görevlilerin hacda vefat etmesi sonucu gerideki evlatları ekonomik açıdan sıkıntı çekebiliyordu. Mehterhane-i Âmire'de çalışırken hacda vefat eden Mehmed Ali adlı Müslümanın geride bıraktığı çocukları kendilerine tahsis edilen rakamın artırılması talebinde bulunmuşlardır. BOA, AE, SMST II, 112/12105 (21 Rebîulâhir 1113/25Eylül 1701)

97 Kıbrıs ŞS, no.10 s. 64.

98 Kibris ȘS no.10 s.20.
} 
Abdullah'la davalık olmuşlardı. Arabulucuların tavassutuyla 575 kuruşa sulh olmuşlardır.99 Mirasla ile ilgili başka bir sıkıntı mirasçıların kendi aralarında anlaşamaması idi. Sofya'nın Şüca Fakih Mahallesinden Ali b. Süleyman hac için Haremeyn'e giderken Mısır sınırları içinde Bulak'ta vefat etmişti. Eşi Zeyneb ve çocukları, el-Hâc Ali'nin kız kardeşlerine babalarından intikal eden 1200 kuruş hisse dolayısıyla dava açmak zorunda kalmışlardır.100

Mirasçlların uğraştığı ikinci mesele ödenmesi gereken borçlar ve ödenmeyen alacaklardır. Üsküdarlı Veli b. Abdullah'ın h.1139/m.1727 yılında hacda vefat etmesi sonucu hanımı Aișe bt. İbrahim, eşi hayatta iken 10 kuruş borç verdiği Halil Beşe b. Ahmed'den davacı olmak zorunda kalmıştır. Halil Beșe'nin Veli b. Abdullah'ın ölmediğini iddia etmesine karşılık, Aişe Hanım o yıl eşiyle birlikte hacca giden Müslümanların eşi Veli'nin Akabebaşı denilen mahalde vefat ettiğine dair şehadetiyle davayı kazanmıştır.101 Hayatta iken birçok borç ilişkisinin olması, hem alacaklılar hem de borçlular sebebiyle mirasçılarını en çok uğraştıranlardan birisi, 1685 yılında Hac dönüşü Bedr-i Huneyn'de vefat eden sakabaşı Dalkozlu el-Hâc Hüseyin Ağa b. Mustafa'dır. Bazı borçlar mirasçıları tarafından çözüme kavuşturulurken bazılar da Saadet-i seniyye yazıcı el-Hâc Abdülkerim Efendi'nin alacağı gibi davalık duruma gelinmiştir. ${ }^{102}$

Hacl yakınlarının uğraştığı üçüncü mesele vefat eden insanların geride bıraktığı ve dönemin sosyal olgularından birisi olan kölelerdir. ${ }^{103}$ Hacda insanların vefat etmesiyle birlikte sahip olunan köleler, efendilerinin mirasçllarıyla davalık olup hürriyetlerine kavuşmuş̧lardır.104 Kayıtlarda iki tür kölelikten bahsedilmektedir. Birincisi mükâtebe yoluyla yani efendisiyle belli bir müddet hizmet karşılığında hürriyetine kavuşan kölelerdir. Bunlar bu zaman dilimini

\footnotetext{
${ }^{99}$ Kıbris ŞS no.14 s.77.

100 Sofya ŞS, no.17 s. 15.

101 Üsküdar ŞS, no.378, vr. 10b.

102 İstanbul Kadı Sicilleri Bab Mahkemesi 46 Numaralı Sicil (H. 1096 - 1097 / M. 1685 1686), s. 162(Hüküm no. 1329; Dalkozlu el-Hâc Hüseyin Ağa'nın diğer borç davaları için bkz. Ístanbul Kadı Sicilleri Bab Mahkemesi 46 Numaralı Sicil (H. 1096 - 1097 / M. 1685 - 1686), s. 167, (hüküm no. 138); s. 188, (hüküm.no. 168); s. 336, (hüküm.no. 368); s. 400, (hüküm.no. 468).

103 Kıbrıs özelinde Osmanlı toplumunda köle sahip olmanın maddi yönden değerlendirilmesi için bkz. Ümit Güler, "Kıbrıs Tereke Kayıtlarında Köleler (17. ve 18. Yy.)" Istem, Konya 2018, say:31 • s. 107- 123.

104 İstanbul Kadı Sicilleri Galata Mahkemesi 46 Numaralı Sicil (H. 1024 - 1029 / M. 1615 - 1620), (Haz. Ayhan Işılk v.d.), Türkiye Diyanet Vakfı İslâm Araştırmaları Merkezi (İSAM), İstanbul 2012, s. 65 hk.no. 40.
} 
doldurduklarında yapılan anlaşma gereği hür olmaktaydı. ${ }^{105}$ Müdebber kölelikte ise bu insanlar efendilerinin ölümüyle hürriyetlerine kavuşmaktaydı. Hacı varislerinin davalık olduğu köle grubu genelde müdebber köleler idi. Bazen köleler hacca gitmeye niyetlenen kimsenin vasiyetiyle şayet hacda vefat ederse hürriyetine kavuștuğu gibi106 bazen de efendisinin hacda vefatıyla mahkemeye gelip müdebber olduğunu ispat etmeye çalışıyordu. Nitekim aslen Rumeli vilayeti Ohri şehrinden el-Hac Hasan b. Mehmed'in hac dönüşü Medine'de vefat etmesi sonucu İbrahim adlı kölesi kendisini köle olarak tutmaya devam eden sakabașı Süleyman Ağa'yı dava edip efendisinin kendisini müdebber eylediğini şahitlerle ispat etmişti. Kadı da İbrahim'in azat edildiğine hükmetmiştir.107

Hukuki bir sebep vesilesiyle kadı sicillerinde yer alan vefat etmiş hacıların dışında hac yolunda vefat edip kayda girmemiş, kervandan ayrılıp yolunu kaybetmiş insanların bulunması işin mukadderat kısmındandır. Bazıları Hac esnasında kaybolmuş ve kendisinden bir daha haber alınamamıștır. Örneğin Üsküdarlı El-Hâc Mehmed b. Abdullah Hac yolunda kaybolmuş kendisinden bir daha haber alınamamıștır. Bundan dolayı İskender adlı kölesi müdebber olduğu için El-Hâc Mehmed'in hanımı Hesnâ Hâtun talebiyle azad edilmiştir. ${ }^{108} \mathrm{Bu}$ kayıplardan bazılarının hayatta kaldığı ve vatan-ı aslîsine dönmeyip şehirlere yerleştiği görülmektedir. Bir boşanma davası sebebiyle kayda girmiş olan bir belgede, Üsküdar Solak Sinan Mahallesi'nden Seyyid Halil b. Salih adlı bir Müslüman hac sonrası memleketine gelmeyip Kahire'ye yerleşmiştir.109

\section{Sonuç}

\footnotetext{
105 Mükâtabeli köle örneklerinden biri olarak şunu örnek verebiliriz. Dönemin Eyüp/ Ahmed Dede mahallesinden İsmail b. Hasan'ın H.1047/M. 1637 yılında Hacda vefat etmesiyle Şirin adlı cariyesi mükatebeli köle olduğu için beş yıl hizmet süresi geçtiği için hürriyetine kavuşmuştur. İstanbul Kadı Sicilleri Eyüb Mahkemesi (Havass-ı Refia) 37 Numaralı Sicil (H. 1047 / M. 1637- 1638), (Haz. Salih Kahriman v.d.) Türkiye Diyanet Vakfı İslâm Araștırmaları Merkezi (İSAM), İstanbul 2011,s. 98 (hüküm no. 65).

106 İstanbul Kadı Sicilleri Bab Mahkemesi 46 Numaralı Sicil (H. 1096 - 1097 / M. 1685 1686), s. 137 (hüküm no 102).

107 Ístanbul Kadı Sicilleri Bab Mahkemesi 46 Numaralı Sicil (H. 1096 - 1097 / M. 1685 1686), s. 151 (hüküm no 117).

108 İstanbul kadı sicilleri Üsküdar mahkemesi 26 numaralı sicil (H. 970-971 / M. 15621563), (Haz. Rıfat Günalan v.d), Türkiye Diyanet Vakfı İslâm Araştırmaları Merkezi (ISAM), İstanbul 2010, s. 341 (Hüküm no 744).

109 Üsküdar ȘS, no.402 vr.65b.
} 
Ulaşım vasıtalarının ve yöntemlerinin büyük ölçüde değişmeden varlığını koruduğu yaklaşık iki asırlık dönemi (16-18. yüzyıllar) içeren bu çalışmada Osmanlı hacılarının tecrübeleri kadı sicilleri ışığında ele alınmıştır. Dikkat çeken ilk nokta, yol sürelerine bakıldığında Osmanlı hacılarının günümüz şartları ile kıyaslanmayacak düzeyde ağır ve meşakkatli şartlarda hac yolculuklarını gerçekleştirmek zorunda kalmalarıdır. Bu sebeple "elHâc" sıfatı Osmanlı toplumunda sayginlık ifade eden unvanların başında gelmektedir. İkinci husus hac bedelleri ve yolculuk için yapılan maddi hazırlıklardır. Dindar kimliğin bir yansıması olarak değerlendirilebilecek hac vasiyetleri sayesinde, kendisi çeşitli sebeplerden ötürü hac yolculuğunu gerçekleştirmesi mümkün olmayanlar, bu ibadetinin maddî külfetini üstlenerek yerlerine tayin/tarif ettikleri vekil hacı adaylarını Haremeyn topraklarına göndermeleridir. Vasiyet hüccetlerinde bedel-i hac rakamları yüzyıllara göre değişebildiği gibi kişilere göre de farklılık gösterebiliyordu Malî bir ibadet olması hasebiyle, hacca niyet eden kişiler hac zamanı yaklaştı̆̆ında yeterli nakde sahip değiller ise, ellerindeki gayrimenkulleri bu amaçla satıyor, meşakkatli, uzun, mukaddes yolculuğa kendilerini her açıdan hazırlıyorlardı. Kimi örneklerde meşakkat hacıların memleketlerine dönmelerinden sonra da devam etmiştir.

Uğruna ölüm de dahil çeşitli zorlukları göze almış hacılar için hac yolculuğu, ömürlerinde gerçekleştirdikleri en mukaddes yolculuktur. Zorluklar, salgınlar, eşkıya baskınları vb. nedenler uzun hac yolculuğunda vefat edenlerin sayısını arttırıyordu. Ölümlerle birlikte çeşitli hukukî muameleler gündeme geliyordu. Hac yolunda vefat eden kişilere ait tereke defterleri konuyla ilgili çalışmalarda araştırmacıların başvurması gereken kaynakların başında gelmektedir. Zengin içeriğinden dolayı tereke defterleri hac olgusunun farklı boyutlarıyla ele alınmasını mümkün kılabilir. Başta Osmanlı döneminde karayolu ile yapılan hac yolculuğu için mühim bir kavşak noktası olan Şam şehrinin kadı sicilleri olmak üzere çeşitli Osmanlı şehirlerinin sicillerinde çok sayıda hac yolunda vefat eden Osmanlıların tereke defterleri yer aldığı gibi hacla ilgili kaleme alınmış çeşitli mahkeme kayıtları da bulunmaktadır. 
Kaynakça

\section{Arşiv Kayıtları}

Boa (Devlet Arşivleri Osmanlı Arşivi), A.Dvnsmhm.D 27/218, 39/354, 116/533, D., 119/833, A. Dvnsrsk. D.78, Ae.Smhd.I, 77/5099, ., Ae, Smst Il, 112/12105, D. Bşm, Mhf.D. 13642, İe, As, 64/5787, İe, Ev, $5 / 567$.

Balıkesir Şs, No.693

Kıbrıs Şs No. 10,11, 13,14, 17.

Sofya Şs, No.12, 17,23.

Üsküdar Şs, 36, 336, 362, 363, 364, 378, 402, 412.

Akkaya Deniz, (1999) Üsküdar Kadılığı 420 Numaralı Seriyye Sicili Defteri 1159-1160/ 1747-1748), Marmara Üniversitesi S.B.E.,.

Bilal, Metin, (2015) 45 No'lu Kırım Kadı Sicilinin Trankripsiyonu Ve Değerlendirilmesi, Karadeniz Teknik Ü. Sbe, (Yayınlanmamış Y. Lisan Tezi) Trabzon.

Çelik, Dilek, (2011) 67 A 90 Nolu Ve 1017-1022(1608-1613) Tarihli Kırım Hanlığı Kadıasker Defteri (Tahlil Ve Transkripsiyon) Sakarya Üniversitesi Sbe (Basılmamış Y. Lisans Tezi) Sakarya.

Divân-I Hümâyûn Sicilleri Diyarbekir Ahkâm Defterleri (H.1155-1167 / M. 1742-1754) Haz. Ahmet Zeki İzgöer Dicle Üniversitesi İlahiyat Fakültesi Diyarbakır 2016.

İstanbul Ahkâm Defterleri, İstanbul"Da Sosyal Hayat, (Haz. A. Tabakoğlu V.D.) İstanbul 1997, I-I.

İstanbul Kadı Sicilleri Bab Mahkemesi 46 Numaralı Sicil (H. 1096 - 1097 / M. 1685 - 1686), Haz. Sabri Atay Vd., Türkiye Diyanet Vakfı İslâm Araştırmaları Merkezi (İsam), İstanbul 2011.

İstanbul Kadı Sicilleri Bab Mahkemesi 54 Numaralı Sicil (H. 1102 / M. 1691), (Haz. Hüseyin Kılıç V.D.) Türkiye Diyanet Vakfı İslâm Araştırmaları Merkezi (İsam), İstanbul 2011.

İstanbul Kadı Sicilleri Balat Mahkemesi 2 Numaralı Sicil (H. 970 - 971 /

M. 1563). Haz. Mustafa Akman Vd., Türkiye Diyanet Vakfı İslâm Araştırmaları Merkezi (İsam), İstanbul 2011.

Istanbul Kadı Sicilleri Eyüb Mahkemesi (Havass-I Refia) 37 Numaralı Sicil (H. 1047 / M. 1637- 1638), (Haz.Salih Kahriman V.D.) Türkiye Diyanet Vakfı İslâm Araştırmaları Merkezi (İsam), İstanbul 2011. İstanbul Kadı Sicilleri Galata Mahkemesi 37 Numaralı Sicil (H. 1022 1024 / M. 1613 - 1615). Haz. Rasim Erol Vd. : Türkiye Diyanet Vakfı İslâm Araştırmaları Merkezi (İsam), İstanbul 2012. 
İstanbul Kadı Sicilleri Galata Mahkemesi 46 Numaralı Sicil (H. 1024 1029 / M. 1615 - 1620), (Haz. Ayhan Işık V.D.), Türkiye Diyanet Vakfı İslâm Araştırmaları Merkezi (İsam), İstanbul 2012.

İstanbul Kadı Sicilleri Galata Mahkemesi 65 Numaralı Sicil (H. 10511053 / M. 1641 - 1644). Haz. Sabri Atay, Vd., Türkiye Diyanet Vakfı İslâm Araştırmaları Merkezi (İsam), İstanbul 2012.

İstanbul Kadı Sicilleri İstanbul Mahkemesi 18 Numaralı Sicil (H. 10861087 / M. 1675 - 1676). Haz. Salih Kahrıman Vd., Türkiye Diyanet Vakfı İslâm Araştırmaları Merkezi (İsam), İstanbul 2010.

İstanbul Kadı Sicilleri Rumeli Sadareti Mahkemesi 21 Numaralı Sicil (H. 1002-1003/M. 1594-1595), Haz. Rasim Erol Vd. Türkiye Diyanet Vakfi İslâm Araştırmaları Merkezi (İsam), İstanbul 2011. İstanbul Kadı Sicilleri Üsküdar Mahkemesi 26 Numaralı Sicil (H. 970971 / M. 1562-1563), (Haz. Rifat Günalan V.D), Türkiye Diyanet Vakfı İslâm Araştırmaları Merkezi (İsam), İstanbul 2010.

İstanbul Kadı Sicilleri Üsküdar Mahkemesi 84 Numaralı Sicil (H.9991000/M.1590-1591). Haz. Rıfat Günalan Vd. Türkiye Diyanet Vakfı İslâm Araștırmaları Merkezi (İsam), İstanbul 2010.

Küçükoğlu, Mustafa Itri (2015) Üsküdar Mahkemesi 510 Numaralı Ser'iyye Sicilinin Transkripsiyon Ve Değerlendirmesi: 1782-1783 (H. 1196-1197),Harran Üniversitesi Sbe, (Basılmamış Y. Lisans Tezi) Şanlıurfa.

\section{Kaynak Eser Ve Araştırmalar}

Akyıldız, A. (1996), Osmanlı Finans Sisteminde Dönüm Noktası Kağıt Para Ve Sosyo Ekonomik Etkileri, Eren Yayıncılık İstanbul.

Armağan, A. L. (2000), "Xvılı. Yüzyılda Hac Yolu Güzergâhı Ve Menziller (=Menâzilü'l-Hacc)", Osmanlı Araștırmaları, İstanbul, S: $\mathrm{Xx}$, Ss. 73- 118.

Atalar, M. (1995), "Emîr-İ Hac" Dia, İstanbul, Xl, 131-132.

Atalar, M. (1991), Osmanlı Devleti'nde Surre-İ Hümayun Ve Surre Alayları, Diyanet İşleri Başkanlığı, Ankara.

Ayaz, F. Y. (1998) Bahri Memlukler Döneminde Hararmeyn Hizmetleri, Marmara Üniversitesi Sbe (Basılmamış Y. Lisans Tezi) İstanbul.

Bakkalzâde D. F. M. P., (1995) Zübde-Í Vekaiyat,(Tahlil Ve Metin) 1066-1116/1656-1704), (Haz. Abdülkadir Özcan) Ttk, Ankara

Barbir, K. K. (1980) Ottoman Rule In Damascus : 1708-1758, Princeton University, Princeton.

Barkan, Ö. L. (1966) "Edirne Askeri Kassamı'na Ait Tereke Defterleri (1545-1659)" Belgeler (Türk Tarih Belgeleri Dergisi), Ankara, C. Iı, Say. 5-6. Sayı, S. 1-473. 
Bilmen, Ö. N., (1951)Hukuk-I İslâmiyye Ve Istılahatı Fıkhiyye Kamusu, İstanbul Üniversitesi Hukuk Fakültesi, İstanbul, I-VI.

Blunt, W. S. (2011), İslamın Geleceği, Trc. M. Fatih Karakaya, Ayrıntı Yayınları, İstanbul.

Bozkurt, F., (2011)Tereke Defterleri Ve Osmanlı Maddi Kültüründe Değişim (1785-1875 İstanbul Örneği) Sakarya Üniversitesi Sbe, Sakarya.

Bozkurt, F., (2013) "Osmanlı Dönemi Tereke Defterleri Ve Tereke Çalışmaları" Türkiye Araştırmaları Literatür Dergisi, Say. 22, S. 193-229.

Bozkurt, F. (2003) "Yetimi Kolla, Malını Koru! Tereke Defterleri Ve Yetim Malları (1785-1875)" Trakya Üniversitesi Edebiyat Fakültesi Dergisi, Ocak-2012, Cilt: 2, Sayı: 3, S. 69-90

Bozkurt, N. (2003),"Mehdî-Bilâh" Dia İstanbul, Xxvilı,377-379.

Canbakal, H., (2009)17. Yüzyılda Ayntab: Osmanlı Kentinde Toplum Ve Siyaset, Trc. Zeynep Yelçe, İletişim Yayınları, İstanbul.

El-Basrî, Ebû Bekr Ahmed B. Amr B. Abdilhâlik El-Bezzâr (Ö. 292/905), (1988) El-Bahrü'z-Zehhâr (El-Müsned) (Nşr. Mahfûzu'rRahmân Zeynullâh), , Müessesetü 'Ulûmü'l-Kur'ân - Mektebetü'l'Ulûm Ve'l-Hikem, Beyrut-Medine, I-Xvill.

El-Makdîsî, Ebü'l-Kâsım Şehabeddin Abdurrahman Ebû Şame, (V.665/1268), (2010/1431) El-Müzeyyel Ale'r-Ravzateyn : (Tarihü'd-Devleti'l-Eyyubiyye Ma Ba'de Salahiddin) Dımaşk : Darü'r-Risaleti'l-Alemiyye ; Beyrut : Darü'l-Beşairi'l-İslamiyye, I-Il. Erkan, N., (2015), Osmanlı Üsküdar'ında Toplumsal Hayat (18. Asır Üsküdar'da Müslim-Gayrimüslim İlişkileri), Üsküdar Belediyesi, İstanbul.

Erken, A., (2017) Xvıll. Yüzyıl Osmanlı Şam Valilerinin Emirü'l-Hacc Olarak Hizmetleri, Kocatepe Üniversitesi Sbe, (Basılmamış Doktora Tezi) Afyonkarahisar.

Evliya Çelebi, (V.1095/1684), (2005) Evliya Çelebi Seyahatnamesi:, Haz. Yücel Dağlı, Seyit Ali Kahraman, Robert Dankoff, Yapı Kredi Yayınları, İstanbul, I-Ix.

Eyüp Sabri Paşa (V.1308/1890), (2018) Mir'atü'lHaremeyn=Haremeyn Tarihi Haz. Ömer Faruk Can, Zehra Can Yazma Eserler Kurumu Başkanlığı, İstanbul.

Faroqhi, S., (1995)Hacılar Ve Sultanlar: Osmanlı Döneminde Hac : 1517-1638, Trc. Gül Çağalı Güven. Tarih Vakfı Yurt Yayınları İstanbul. 
Faroqhi, S., (2009) Orta Halli Osmanlılar:17.Yüzyılda Ankara Ve Kayseri'de Ev Sahipleri Ve Evler, (Trc. Hamit Çalışkan), Türkiye İş Bankası Kültür Yayınları, İstanbul.

Gemici, N., (2009) "Evliya Çelebi'nin Hac Ziyareti Ve Seyahatname'nin Hac Bölümünün Kaynakları", Diyanet İlmi Dergi, , C: Xlv, Say.: 3, S. 77-102.

Genç, S., (2005) “Hac Yolunda Ölüm: Xvııı. Yüzyılda Balıkesirli Hacılar” Balıkesir Sempozyumu: Tebliğler Kitabı, 17-20 Kasım Balıkesir, S.312-317.

Güler, M. (2002) Osmanlı Devletinde Haremeyn Vakıfları (16. Ve 17. Yüzyıllar) İstanbul.

Güler, Ü., (2018) "Kıbrıs Tereke Kayıtlarında Köleler (17. Ve 18. Yy.)" Istem Konya, Say:31•S. $107-123$.

Gündoğdu, A., (2008) "Pilgirim And Traveler: Hajnamas From The Volga-Ural Region", Proceeding of The Third International Symposium On Islamic Civilation In Volga-Ural Region, Ufa.

Hallak, Şeyh Ahmed El-Bedirî, (1995) Berber Bedrinin Günlügü:17411762: Osmanlı Taşrasına İliş̧kin Olaylar Nşr. Ahmet İzzet Abdülkerim Trc. Hasan Yüksel Akçağ Yayınları, Ankara.

İbn Cübeyr, Ebü'l-Hüseyin Muhammed B. Ahmed (V.614/1217), (1980) Rihletu İbn Cübeyr, Dâru's-Sadr, Beyrut.

İlgürel, S., "Abdurrahman Hibri'nin Menasik-İ Mesalik'i", İstanbul Üniversitesi Edebiyat Fakültesi Tarih Enstitüsü Dergisi, İstanbul 1975, Say.6 , S.111-128.

Koyuncu, M., (2013) “Velîd I” Dia, İstanbul, Xlııl, 30-31.

Kurşun, Z. (2017) “Hac Ve İktidar:Haremeyn'de Erken Dönem

Osmanlı İmar Faaliyetleri" Fsm İlmî Araștırmalar İnsan Ve Toplum Bilimleri Dergisi İstanbul, Ix,281-311.

Küçükaşcl, M. S, (2007)Abbasiler'den Osmanlılar'a Mekke-Medine Tarihi, Yeditepe Yayınevi İstanbul.

Küçükaşçı, M. S, (1998) “Hicaz” Dia; İstanbul, Xvıı,432-437.

Mahluf, M., (2006) Evkafu Nisai's-Selâtine'l- Osmaniyyîn: Vakfiyetü Zevceti's-Sultan Süleyman Kanuni Ale'l-Haremeyni'ş-Serifeyn. Darü'l-Afaki'l-Arabiyye, Kahire.

Me'mun Abdullah Aslan Beni Yunus, (1997) Kafiletü'l-Haci'ş-Şami Fî Sarkiyyi'l-Ürdün Fîl'l-Ahdi'l-Osmani : 1516-1918,: Vizaretü's-Sekâfe, Amman.

Merginanî, Ebu'l-Hasen Burhaneddin Ali B. Ebî Bekir Î (V.593/1197) (1991)El- Hidaye Şerhu Bidâyeti'l Mübtedî, Eda Neşriyat İstanbul, I-Iı (Mücelled). 
Mert, T., (20099 "Arşiv Belgelerine Göre Dede Efendi'nin Veda Haccı" Türk Edebiyatı Aylık Fikir Ve Sanat Dergisi, Aralık, Cdxxxıv, 10-14.

Mutaf, A., (2002) Xvıl. Yüzyılda Balıkesirli Kadınlar, Dokuz Eylül Üniversitesi Sbe, (Basılmamış Doktora Tezi) İzmir.

Özaydın, A. (1996) "Hac:Tarihçe” Dia, İstanbul, Xıv, 399-400.

Özcan, A., (1996)“ Hac: Osmanlı Dönemi” Dia, İstanbul, Xıv, 400-408.

Özköse, K. (2007) "Mağrib Müslümanlarının Hac Organizatörlüğünü Yapan Tarikat: Salihiyye Tarikatı Ve Asafi Ribatı" Cumhuriyet Üniversitesi İlahiyat Fakültesi Dergisi, Xı/1 Sivas, S. 29-49

Öztürk, S., (1995) İstanbul Tereke Defterleri: Sosyo-Ekonomik Tahlil: Askeri Kassama Ait: Onyedinci Asır, Osmanlı Araştırmaları Vakfı İstanbul.

Pamuk, Ş., (1999), Osmanlı Imparatorluğu'nda Paranın Tarihi, Tarih Vakfı Yurt Yayınları, İstanbul.

Sahillioğlu, H., (1965) Bir Asırlık Para Tarihi 1640-1740 (Basılmamış Doçentlik Tezi ) İstanbul.

Sak, İzzet-Çetin, Cemal, (2005) "Xvıı. Ve Xvııı. Yüzyıllarda Osmanlı Hac Menzilleri" Selçuk Üniversitesi İlahiyat Fakültesi Dergisi, Konya, Say.19s. 199-260.

Taberi, Ebû Cafer İbn Cerir Muhammed B. Cerir B. Yezid (V.310/92), (1967) Târihü't-Taberi : Târihü'l-Ümem Ve'l-Mülûk Thk. Muhammed Ebü'l-Fazl İbrâhim . Beyrut, , I-Ix.

Telli, H., (2018) Osmanlı Dönemi Üsküp Vakıfları, Ankara Üniversitesi Sbe, (Basılmamıș Doktora Tezi) Ankara.

Uzunçarşılı İsmail Hakkı, (1958) "Sultan İkinci Murad'ın Vasiyetnâmesi” Vakıflar Dergisi, Ankara, Vl, 1-17.

Uzunçarşılı, İsmail, Hakkı (1984) Mekke-İ Mükerreme Emirleri, Ttk, Ankara.

Yılmaz, A., (2001) Osmanlı Dönemi Edirne - Mekke Hac Yolu H. 10081214 / 1600-1800. Marmara Üniversitesi Sbe (Basılmamış Y. Lisans Tezi) İstanbul. 